University of Louisville

ThinkIR: The University of Louisville's Institutional Repository

Electronic Theses and Dissertations

$5-2014$

\title{
Public art in urban parks.
}

Taylor Crush, 1990-

University of Louisville

Follow this and additional works at: https://ir.library.louisville.edu/etd

Part of the Art and Design Commons

\section{Recommended Citation}

Crush,, Taylor 1990-, "Public art in urban parks." (2014). Electronic Theses and Dissertations. Paper 295. https://doi.org/10.18297/etd/295

This Master's Thesis is brought to you for free and open access by ThinkIR: The University of Louisville's Institutional Repository. It has been accepted for inclusion in Electronic Theses and Dissertations by an authorized administrator of ThinkIR: The University of Louisville's Institutional Repository. This title appears here courtesy of the author, who has retained all other copyrights. For more information, please contact thinkir@louisville.edu. 


\title{
PUBLIC ART IN URBAN PARKS
}

\author{
By \\ Taylor Crush \\ B.F.A., University of Louisville, 2012
}

\begin{abstract}
Thesis
Submitted to the Faculty of the

College of Arts and Sciences of the University of Louisville

In Partial Fulfillment of the Requirements

For the Degree of
\end{abstract}

\author{
Master of Arts \\ Department of Fine Arts \\ University of Louisville, \\ Louisville, Kentucky
}

May 2014 



\title{
PUBLIC ART IN URBAN PARKS
}

\author{
By \\ Taylor Crush \\ B.F.A, University of Louisville, 2012
}

\begin{abstract}
A Thesis Approved on
\end{abstract}
April 18, 2014

by the following Thesis Committee:

John Begley

Peter Morrin

Thomas Maloney 


\section{ACKNOWLEDGMENTS}

My inspiration for this thesis came from not only my personal interests, but also my undergraduate and graduate education at the University of Louisville. It is through the support, teachings, and guidance from my professors, parents, and husband that I was able to pursue my education at my highest potential. Therefore, I would like to thank the following:

First, I must thank my Thesis Committee: Professor John Begley, Professor Peter Morrin, and Dr. Thomas Maloney. Their patience, critiques, and guidance throughout my graduate career have been valued and appreciated.

Second, I wish to thank my undergraduate professors, especially Professor Scott Massey. It was in his sculpture classroom where I realized my passion for public art, and that would not have occurred without his constant support, questions, and discussions.

Third, I would like to thank my parents, Stephen and Susan Crush, who throughout everything in life provide me with constant support. Their encouragements helped me pursue my educational goals at the University of Louisville.

Lastly, I would like to thank my husband, Gregory, for proofreading, discussing, and listening to my thoughts throughout my research. His support and patience helped me achieve a Master's Degree at the University of Louisville. 


\section{ABSTRACT \\ PUBLIC ART IN PUBLIC PARKS}

Taylor Crush

May 10, 2014

An analysis of contemporary public art in urban parks reveals challenges concerning the conservation of artworks and the stability of public interest. These issues have been relevant throughout history. Historical evidence reveals the transition of public art representing a ruling cultural or governmental power to art that represents visions of the public. Despite this change, the continuation of public interest remains a concern as art becomes neglected and misinterpreted. Efforts to properly educate, provide formal evaluations, and support daily maintenance of the art are a constant concern for arts organizations. After explicating public art in public spaces and art in private gardens, I will explore what constitutes a public in contemporary times, share insight on current critical responses to public art in urban spaces, and provide conclusions that contemporary urban parks are largely based on traditional park and garden designs by analyzing Louisville's Waterfront Park as a case study. 


\section{TABLE OF CONTENTS}

ACKNOWLEDGEMENTS ................................................ iii

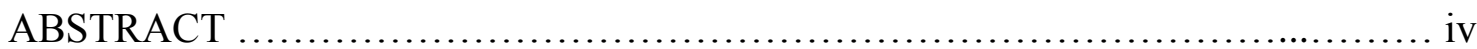

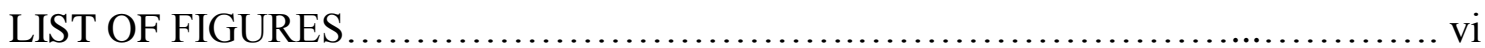

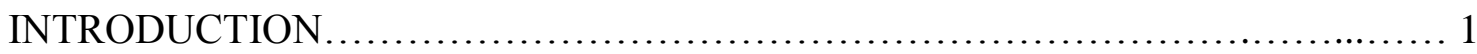

CHAPTER I: A Brief History of Public Art in Public Spaces ....................... 4

CHAPTER II: A Brief History of Art in Gardens to Art in

Public Parks .................................................. 21

CHAPTER III: Constructing a Public through Urban

Planning, Nature, and Artistic Design .......................... 40

CHAPTER IV: Contemporary Issues Concerning Public Art:

the Public, Evaluation, and Conservation ..................................... 58

CHAPTER V: Case Study: Louisville Waterfront Park ........................... 75

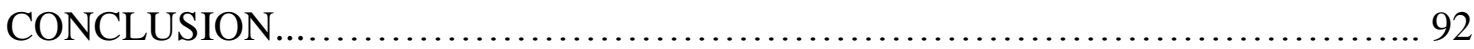

REFERENCES ........................................................ 95

CURRICULUM VITA....................................................... 101 


\section{LIST OF FIGURES}

FIGURE

PAGE

1. The gardens of the Villa Farnese and of the Casino, Caprarola:

I General Plan, after Lebas....

2. Villa Medici, Rome. From G. Lauro, Antiquae Urbis splendor, Rome 1612-14. Dumbarton Oaks, Washington, D.C .28

3. Hercules challenging the dragon that guards the golden apples: design for a mechanical theatre. Engraving by G.B. Aleotti, 1589

4. Levels and methods of leveling. From N. Bion Traité de la construction... des instrumens mathématiques. Paris, 1709

5. La Parnasse français, engraving by Maisonneuve, from a painting by Lajone. Bibliotheque Nationale, Cabinet des Estampes, Paris.........34

6. "Time use on an average work day for employed persons ages 25 to 54 with children" graph, Bureau of Labor Statistics, American Time Use Survey

7. "Time use on an average weekday for full-time university and college students" graph, Bureau of Labor Statistics, American Time Use Survey .43

8. Jan Gehl's Condition vs. Activity Chart. .46 
9. "Percent of people aged 15 years and older who engaged in sports or exercise activities on an average day, by specific activity, 2003-06" Bureau of Labor Statistics

10. "Percent distribution by age of people aged 15 years and older who engaged in sports or exercise activities on an average day, by activity, 2003-06" Bureau of Labor Statistics ................... 52

11. Louisville Waterfront Park Map, “3 mile Walking/Jogging Route”.....81

12. City of Louisville Citizen Survey, "Safety on Various Public Areas" 87

13. City of Louisville Citizen Survey, "Importance of Aspects of

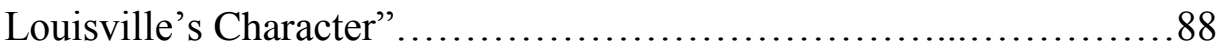




\section{INTRODUCTION}

Public art has been a genre in the art world for centuries. However, throughout time, the way in which public art is viewed has altered. In early centuries, especially during the Renaissance, public art was a tool used by wealthy patrons to retain control over the cultures of the public. This was especially common from religious and government patrons. Even though types of public art continue to reveal concepts concerning religion or government topics, the art concepts have expanded to challenge the existing issues, thoughts, and beliefs that are related to and influenced by unique community and cultural identities. Public art has proven itself to be more accessible and inviting to people than before by inspiring a public to think outside the box and by including the public during the development of the projects.

This new direction for public art as art for the people, has proven to be dominant in public art development over the past half century as more and more artists are commissioned to produce works that are unique to a community. But despite the presumed success of this assumption that art should be "art for the people," there are major issues concerning today's public art and its expanding development as a necessary component of park and art design. Three of these issues are analyzed throughout this essay: stability of public interest, useful evaluation methods, and the importance of conservation. 
The stability of public interest includes thorough research of the community and space where the art will reside and education opportunities for the public after installation. A properly researched public art project requires focus from both the artist and the organizing entity commissioning the project to evaluate and decipher a community's history, interests, and visual representation of themselves. "Research is intrinsic to public art practice... and is integral to the process of finding lines of communication with a "public." ${ }^{11}$ Research also includes the creation of educational tools for the audience after the artwork is installed. Many people misinterpret a work of art. This causes dislike, neglect, or, to the dismay of the artist, the liking of a concept that wasn't intended for the work. Today artists or organizations often create websites, QR codes, or tours about the work of art to make them accessible and provide the clear message about the art to reach the audience. This not only helps the artwork become an understandable and valuable icon for decades, but also sets parameters for questions that could be asked during evaluation of the artwork.

Evaluation, like research and education, is vital to the continued success of a work of art as well as the promotion and development of future projects. However, there are no single correct or predetermined guidelines to aid an organization with the evaluation process. This issue calls for a public art language to be developed so that past, present, and future public artworks may be fully appreciated. Jeremy Hunt and Jonathan Vickery state, "[a]rt criticism has been prodigious regarding public art's role in the 'beautification' of otherwise neglected social space,"2 however, the art also does so much

\footnotetext{
${ }^{1}$ Jeremy Hunt and Jonathan Vickery, "Public Art in the $21^{\text {st }}$ Century," GROVE Art Online, accessed January 10, 2014, www.oxfordartonline.com.

${ }^{2}$ Hunt and Vickery, "Public Art in the $21^{\text {st }}$ Century."
} 
more for a community, city, or local park. The additional benefits of a work of art in an industrious area include economic boosts for nearby businesses, an increase in activities from visitors and city dwellers, and community bonding through the identification of the art. Evaluations could help determine the benefits a work of art brings to an area. When these benefits are fully developed and understood, attention can be more easily focused on conservation of the treasured, community-valued art.

Conservation ultimately plays a key role in the overall lifespan of a public art project. Initiating organizations generally have not allotted money for conservation of the project after its installation. As artists produce works that contain new materials and technologies that have not previously been used in the outdoor public art realm, there is a need for greater attention for the preservation of new work. Setting aside money for normal wear-and-tear treatments to public art may actually save more money as well as lengthen the life of the work.

Public art has been around for centuries and has had both failures and successes. This thesis focuses on how changing public interests, the omission of evaluating the success or failure in meeting the goals of particular projects, and the lack of provision of funds for ongoing preservation influences the ultimate success and acceptance of public art projects in urban areas. Each chapter provides examples of historical and contemporary works of art, the evolution of public art spaces - especially gardens and parks, the way urban planning constructs a public, and a case study of Louisville's Waterfront Park in the lens of these issues. A dialogue about the future of public art will occur, ensuring that public art will remain a valued interest for a person's daily life, culture, and community. 


\section{CHAPTER ONE}

\section{A BRIEF HISTORY OF ART IN PUBLIC SPACES}

Public art in urban parks are the contemporary forms of art that has been used in public spaces and art in private gardens. ${ }^{3}$ Even though art for public viewing has been relevant for centuries, the term public art as used today describes a fairly new concept. Cher Krause Knight defines this modern concept of public art as art “...in the service of the people, rather than ruling factions [of]"4 as compared to the art of the $16^{\text {th }}-18^{\text {th }}$ centuries.

While the following examples of art and architecture are early formative examples in the timeline of public art history, their contribution as progressive forms of public art remain important today. Beginning with the High Renaissance and ending with contemporary urban parks in major United States cities, this brief overview of into the history of art in public spaces will reveal the importance of architecture and city design as public spaces that show the transition of art as a tool of ruling powers to art that expresses the unique identity of its originating source. This progression also foreshadows the future separation of architecture and public art into their own entities.

In this thesis, a "public" is initially defined through a hierarchical construct. Both the religious and government authorities at the top of the hierarchy defined a public

\footnotetext{
${ }^{3}$ For the remainder of this chapter the primary focus of discussion will be art in public spaces. Chapter Two reveals insight on the influential progression of art in private gardens to art in urban parks.

${ }^{4}$ Cher Krause Knight, Public Art: Theory Practice and Populism (Massachusetts: Blackwell Publishing, 2008), 2.
} 
according to their needs and desires in order to build and control their audience. During the Renaissance, the Papacy, as the ruling religious faction, funded the arts to define their public audience as a religious group. As the United States began, the nation-state relationship ensured a governmental influence over its public through art. As democracy developed, the decentralization of ideas and resources redefined the term "public." This "public" now encompasses new groups of individuals and communities who influence and contribute to public art according to their needs and desires rather than the needs and desires of a ruling class. Whether the work of art is a temporal work at a festival, a permanent work, or a community gathering space, current public art practices will constantly seek to provoke thought, community interaction and inspiration in their spaces. Throughout the transition of public art as a representation of a ruling entity to a work of art inspired by and generated for the people, the public has always been a focus for public art for centuries.

Art in previous centuries related closely to architecture. Architecture provided opportunities for artistic embellishments on the building's functional interior and exterior surfaces. The building's function also defined the type of public interaction, which in turn influenced the art. For example, the layout of a Catholic Church in the $16^{\text {th }}$ century revealed two things. First, the crafted interior and exterior surfaces could contain paintings, inscriptions, and sculptures that could teach Church doctrine; and second, the building, designed for public worship and therefore a public place, could enhance the power, influence, and structure of the church in relation to its congregation. The art in and on the building are examples of the early concept of public art. In this case the art was employed by a ruling faction to further its religious and authoritarian power. 
Throughout the $16^{\text {th }}$ and $18^{\text {th }}$ centuries, many publics observed art in the local architecture or public squares that depicted subjects “...ranging from countless portraits of ancient rulers, designed to bolster confidence and inspire loyalty; to massive pieces of street furniture, like triumphal arches proclaiming the military prowess of particular regimes." ${ }^{\text {Th }}$ The High Renaissance artists and architects in the $16^{\text {th }}$ century created artwork and designs that were no exception to this idea. Utilizing talent along with the technology and techniques accumulated throughout the entire Renaissance period, not to mention support from generous patrons, craftsmen and architects were able to produce wellknown forms of art and architecture for public spaces that remain prominent examples of public art. Because the most funding for the arts came from the Papacy, most of the wellknown works of art and architecture in public spaces at this time related to religious worship.

Pope Pius IV, an avid patron of the arts, commissioned artists, craftsmen, and architects to portray the awe of God in Rome by altering the city's urban design. His accomplishments included the design of new city streets which incorporated plazas and the restoration of many monuments from the classical antiquity. He also commissioned one of the most well-known contributions to the city: the Sistine Chapel.

The Sistine Chapel is home to one of Michelangelo di Lodovico Buonarroti Simoni's most famous works created in the early 1500s. Michelangelo painted religious scenes on several panels across the ceiling of the Chapel. These scenes were illustrated from different books in the Bible. The figures across the large paneled ceiling featured different subjects (prophets and sibyls, nudes, bronze-colored nudes, etc.), and the

\footnotetext{
${ }^{5}$ Knight, Public Art, 1-2.
} 
painting style caused his figures to resemble polychrome sculpture. ${ }^{6}$ Each section that resides outside of the panels share the same light source of the altar. Many artists in this century painted their work based on the light source coming from windows, however, Michelangelo depicted light in his paintings coming from the altar, emphasizing the source of light as Divine. ${ }^{7}$ Located in the Vatican in Rome, The Sistine Chapel ceiling remains a source of inspiration and awe for the visitors that view it daily.

The grandiosity of this era continued under another strong patron of the arts, Pope Julius II. Throughout his Papacy, religious monuments, funeral monuments, and churches, such as St. Peter's Basilica, were built. Each housed many sculptures and paintings that shared the religious styles of the Renaissance period. As the papal court continued to remain the dominant patron for the arts, commissioned works during this time continued to show a love for Christ through the ornamentation of Churches, funeral monuments, and facades of town buildings.

In the later part of the $16^{\text {th }}$ century, city projects also included art in public spaces that related to government. These publicly dedicated spaces were called public squares. The layout of a public square generally consisted of a central, concrete space surrounded by buildings on all four sides. Commissioned by Pope Paul III, Michelangelo redesigned the Piazza del Campidoglio, located on Capitoline Hill in Rome. This public square was unique in that its central space was a trapezoidal plaza, surrounded by three buildings that were important to Rome's government. ${ }^{8}$ Construction began in the 1530 s and continued after Michelangelo's death in 1564. The three buildings received new facades, and a

\footnotetext{
${ }^{6}$ Frederick Hartt, Michelangelo (New York: Harry N. Abrams, Inc., 2004), 9.

${ }^{7}$ Hartt, Michelangelo, 9.

8 “A View on Cities: Rome," accessed January 10, 2014, http://www.aviewoncities.com/rome/piazzadelcampidoglio.htm.
} 
bronze statue of Emperor Marcus Aurelius resides in the center of the square as a symbol of leadership. Public squares like this created casual space for public discourse, meetings, and even unofficial market spaces. The function of this space and the purposeful placement of the centered sculpture, more closely resembles public art in urban environments today.

Following the examples of the High Renaissance, the 17th century brought a new style of art known as Baroque. Baroque art and architecture also focused on religion as the primary subject in public spaces. However, this style displayed more dramatic characteristics. Under the influence and patronage of the Roman Catholic Church, "which had decided at the time of Council of Trent, in response to the Protestant Reformation, that the arts should communicate religious themes in direct and emotional involvement," Baroque artists created figurative sculptures that aroused strong emotion in their viewers. Intended for a faithful public, artists included precious materials such as gold, recognizable symbols, descriptive features in their figures, and biblical, story-like representations to conjure emotional response.

A well-known example of a Baroque sculpture is Gian Lorenzo Bernini's St. Theresa in Ecstasy. Constructed in Coronaro Chapel in 1652 as part of the Church of Santa Maria della Vittoria in Rome, St. Theresa in Ecstasy resides above the altar, where the figure of an angel above St. Theresa holds an arrow. According to scripture, this arrow pierced St. Theresa into a state of God-loving ecstasy which “...make[s] visible the movements of a soul on fire with the love of God." ${ }^{10}$ Bernini is known for creating

\footnotetext{
${ }^{9}$ Giovanni Careri, Baroques (New Jersey: Princeton University Press, 2003), 61-79.

${ }^{10}$ Michael Snodin and Nigel Llewellyn, eds., assisted by Joanna Norman. Baroque, Style in the Age of Magnificence (London: V\&A Publishing, 2009), 96.
} 
sculptures so dramatic that they resemble freeze-frames of an acting scene, and this sculpture is no exception. ${ }^{11}$ The dramatic shadows, sun ray sculpture behind the altar, and visible vulnerability of St. Theresa, attempted to express to the Christian public that God is love. Playing with light and shadow, fear and awe, devotion and ecstasy, Bernini created a tribute in honor of the Coronaro family that was deemed appropriate for the Church and a public reminder that submitting to God's will is love.

Architecture during the Baroque period emphasizes the drama of shadow and light. Several public squares became prominent attractions to the city's design. One of the most famous squares is Piazza di San Pietro (St. Peter's Square) which was completed in 1667. Architect Gian Lorenzo Bernini created a circular-shaped plaza, surrounded by colonnades, and placed a central obelisk from Egypt in the center of the square. The symmetrical, dramatic columns (four rows deep) create bold shadows throughout the day and the 140 saints along the top of the column walls reveal dramatic poses and rich decoration, expressing the Baroque style. While the space may seem intimidating based on its austere qualities and large scale, those who were faithful to the church would instead find it appealing: "[s]urrounded by colonnades topped with 140 statues of the saints, the square seems to embrace the approaching faithful." 12 This large square provides ample room for public meetings and public worship.

Following the Baroque period is the Age of Neo Classicism. Neo Classicism is defined by art and architecture that rids itself of the excess symbolism, design, and drama developed from the Baroque period, and prides itself once again in the purity and simplicity of the antiquity. As the focus of the Neo Classical period shifts from Europe to

\footnotetext{
${ }^{11}$ Snodin, Llewellyn, eds., Baroque, 98.

${ }^{12}$ Trevor Howells, The World's Greatest Buildings (San Francisco: Fog City Press, 2002), 39.
} 
the emerging democracy of the United States, trends of art in public spaces change from religious intention to government design. Most of the art and architecture were commissioned by and for the government.

During this time in the United States, the Neo Classical style inspired some artists in ways that kept their talent alive, despite the lack of patronage. Based on the vigorous support for the new government, portraiture and sculpture busts of city leaders and influential government officials became a dominant art form. The reintroduction of portraits and busts seems to travel "backwards" on the timeline of public art, but it actually is an example of a growing pride for the new democracy, which places it in new historical context.

Architecture in the United States brought back the simplicity and purity of the antiquity. Many prominent buildings became symbols for the people as a form of public art rather than a space for viewing public art. For example, the Capitol in Washington, completed in 1826, revealed inspiration from the Palace of Versailles whose design included terraces, lawns, and garden spaces. ${ }^{13}$ Thomas Jefferson proposed that the building remain in the neoclassical style so that "the elegant proportions of ancient structures would evoke chief values of the Enlightenment: reason, order, and democracy." 14 This building incorporates some decorative facades and currently houses a large collection of statues and historic art. The Capitol, as mentioned before, is a public art symbol for a large public because it "[embraces] the differences among individuals as variant manifestations of a common spirit." 15 Even though an individual citizen can

\footnotetext{
${ }^{13}$ Howells, World's Greatest Buildings, 100.

${ }^{14}$ Howells, World's Greatest Buildings, 100.

${ }^{15}$ Hilde Hein, "What is Public Art?: Time, Place, and Meaning," The Journal of Aesthetics and Art

Criticism, Vol. 54, No. 1 (Winter 1996): 1, accessed January 6, 2014, http://www.jstor.org/stable/431675.
} 
observe the building in private, the purpose of the art and architecture is for an entire community, enhancing its symbolism as public art in addition to its functional qualities of a government building. The grandiosity of the Capitol's construction reveals a spirit dedicated to the newly formed government.

Eventually, statues and sculptural monuments were integrated into public spaces not associated with a building. In 1858, New York began constructing Central Park based on the designs of architects Fredrick Law Olmstead and Calvert Vaux. This was the first official public park in the United States, and was created for the passing public, leisure activities, public events, and nature-lovers. ${ }^{16}$ Interestingly, this park resembled the designs of a public square from the $17^{\text {th }}$ century as it is surrounded on four sides by buildings and continues to be a meeting place for people in the city. Olmstead and Vaux took pride in their landscape design, and declared that its design could stand on its own, without the addition of art monuments or statues.

However, when the park opened to the public, many statues of public figures were gifted to it. They were first installed along the elm trees in the Mall (described to be the most formal section of the park). Over the years, installations of many sculptures and monuments emerged in certain locations of the park. These sculptures included subjects of heroes, animals, whimsical stories, and environmental concerns and conceptual characteristics. "The sculptures and monuments have played a central role in that process and contribute to the Park's status as a complex work of art." ${ }^{17}$ Miller adds, "Observed both at home and from abroad as the cynosure of the burgeoning commercial and

\footnotetext{
${ }^{16}$ Sara Cedar Miller, Central Park, an American Masterpiece (New York: Harry N. Abrams, Inc., in assoc. with Central Park Conservancy), 186.

${ }^{17}$ Miller, Central Park, 188.
} 
industrial metropolis, Central Park quickly became a model for other cities' metropolitan parks and an important catalyst in the $19^{\text {th }}$ century parks movement." ${ }^{\text {18 }}$

In 1872, as other cities developed public parks, Philadelphia became the first United States city to develop a nonprofit organization called Fairmont Park Art Association (now the Association of Public Art), which focused on integrating public art and urban planning. This organization's goal was to incorporate art in the city by first installing artwork in Fairmount Park that was similar to Central Park. Now, the organization has expanded its boundaries beyond the park, and has changed its name to Association of Public Art, so that it may continue its mission clearly and in a broadened perspective. ${ }^{19}$ This organization supported the modern thinking of public art as objects for the people and not as expressions of religious faith or government power.

Throughout the next decade, the United States became a leading country in industry. New inventions during the Industrial Age promoted a growing industry, which created more job opportunities, generating increased urban population, which resulted in congested city living. Overcrowded city neighborhoods were bad for the quality of life. Excessive population growth encouraged the need for green spaces in the city. Distinct from the original private gardens constructed in the previous centuries, these parks were "primarily intended for the working class," 20 and directly influenced the overcrowded city public.

Despite the burgeoning need, the green spaces were put on hold until the 1950s60s due to the Depression in the 1930s. President Roosevelt was determined to enhance

\footnotetext{
${ }^{18}$ Miller, Central Park, 236.

19 "Association for Public Art," accessed January 8, 2014, associationforpublicart.org.

${ }^{20}$ Harriet Jordan, "Public Parks, 1885-1914," The Garden History Society, Vol. 22, No. 1, (Summer 1994): 86, accessed January 6, 2014, http://jstor.org/stable/1587004.
} 
the mental and cultural well-being of the United States. He developed a series of programs within the New Deal that sponsored artistic venues across the country. Becoming the government's largest recorded art funding project, ${ }^{21}$ the Federal Art Program (FPA) called for artists to create sculptures, paintings, murals, and photographs to enhance the welfare of the citizens. These were the first forms of declared "public art" in the United States, as it was art specifically created for a large population.

One of the leading programs within the FPA established from 1934-1942, called the Section of Fine Arts, required that all new buildings set aside one percent of their total cost for artistic decoration. ${ }^{22}$ Knight says, “[t]hrough projects such as post office murals, the Section not only underscored the federal government's presence in communities large and small, but brought art into the realm of the everyday with recognizable subjects depicted through familiar means." ${ }^{23}$ Over 1,300 murals and 300 sculptures were created by contest winners through this organization. ${ }^{24}$ While this was financially beneficial for the art community, the program instigated issues of "plop art" (art that was not properly researched and does not fit correctly in its intended environment) in city buildings. While most of the commission requirements specified that the symbolism of the artwork resemble the function of the building where it would reside, the art did not always reflect the purpose as prominently as expected. The concept of artistic place-making was not as defined for these projects, resulting in several works that were created which revealed imagery that the government wished to avoid. A well-known example of such a mural is located at Coit Tower in San Francisco, California. Titled City Life, created by Victor

\footnotetext{
${ }^{21}$ Knight, Public Art, 3.

${ }^{22}$ Knight, Public Art, 4.

${ }^{23}$ Knight, Public Art, 5.

24 “Federal Art Programs," last modified November 12, 2013, www.gsa.gov/portal/content/101818
} 
Arnautoff, this mural contains a radical stance on the artist's view of the city's "proCommunist" connections and depicts a chaotic yet harmonious city street of San Francisco. Newsstands, city workers, cars, people shaking hands and a postman delivering mail are places, actions, and events that the public of San Francisco can relate to in their everyday life ${ }^{25}$ while hidden communist references were placed throughout. The concept in this scene was contradictory to the government's desire that art would revive solidarity across the United States' economic boundaries and classes.

By the late 1960s much public art had shifted again to include a new genre called Earth Art that incorporated the rural landscape, large construction equipment, and materials that came from and transformed the Earth through landscape alteration and design. The artwork during this period reflected the use of the rural landscape and eventually directed attention towards environmental concerns. Artists such as Robert Smithson, Nancy Holt, Michael Heizer, and Walter de Maria, for example, were leaders of this movement with their works Spiral Jetty (1970), Sun Tunnels (1976), Double Negative (1969), and Lightning Field (1977), respectively. This art was "dependent on distance, photography, and major funding," 26 and, while it provided opportunities for artistic pilgrimage, it limited its public. Eventually, these types of artworks were brought down in scale and moved closer to the city, becoming incorporated as part of city parks, where funding was more readily available and a public could more easily engage with the work.

\footnotetext{
${ }^{25}$ Frances K. Pohl, “Art for People, Art Against Fascism,” in Framing America (New York: Thames \& Hudson, Inc., 2008), 410.

${ }^{26}$ Glenn Harper and Twylene Moyer, The New Earthwork: Art Action Agency (New Jersey: isc Press, 2011), 12.
} 
Most earthwork installations were inspired by the art concept of minimalism. The goal of minimalist art is reveal the identity of a subject using its most basic forms. Artist Joseph Beuys integrated ideas of minimalist earth art with a concept he called social sculpture, a term Beuys coined to define art as an integral part of the everyday life of people. Beuys' concept of social sculpture encouraged artists to create work that could be integrated into the public's daily life. His work in Kassel, Germany, called 7000 Oaks, is one of the largest social sculpture projects. The project consists of 7,000 Oak trees planted along roadways, accompanied by a basalt rock at the base of every tree. The project was completed in 1987 after five years of planting. ${ }^{27}$ Beuys' social sculpture concept, blended with environmental art, attempts to make his work as art for the people, rather than art as an attempt to impose ideas, identity, or hierarchies on people.

According to Glenn Harper and Twylene Moyer, “[t] oday’s younger artists and collectives are reversing the direction [of Earth Art], bringing rural and agricultural sites to the cities, reminding urbanites of the hidden hills and streams beneath their feet, mapping migrations, extinctions, and survivals." 28 This type of Earth Art is often referred to as Land Art or Environmental Art which generally includes all site specific art in the landscape, or art projects that involve land reclamation, such as Nancy Holt's Dark Star Park, in Arlington, Virginia. This park project is an example of how art becomes infused into the park design and incorporates artistic forms within the design. Her plan for the park involved lessons in astronomy, concrete tunnels, and pathways that encourage rest, play and thought. She is praised for this park design based on the fact that she was willing to "create 'situations' rather than provide 'monolithic abstractions,"” and produce "work

\footnotetext{
27 “Joseph Beuys, 7000 Oaks," last modified 2012, www.diaart.org/sites/page/51/1364.

${ }^{28}$ Harper and Moyer, New Earthwork, 12.
} 
that 'fuses with' rather than occupies its site." ${ }^{29}$ Her strong involvement with the city, park engineers, urban planners, and urban landscape designers is a prime example of the current progression of art in parks and parks as art.

Other ways in which land art is incorporated in a city landscape can be seen in contemporary urban gardens. These gardens can be private or community-planted spaces which incorporate artistic design and provide a retreat space for their visitors on a much smaller scale than local parks. Houston Center for Contemporary Craft in Houston, Texas, provides a garden space that promotes and educates visitors about craft. This space is free to the public and is available for educational or retreat purposes.

While some artists, like Holt, were trying to incorporate their art into city park design, others were utilizing the National Endowment for the Art's program called "Artin-Public-Places" (AiPP) established in 1967. This program intended to support the following functions of art:

"increasing awareness of contemporary art; fostering aesthetic enhancement and socially-minded redevelopment of public spaces; offering American artists, especially emerging ones, opportunities to work in public contexts; supporting artistic experimentation; and engendering direct community involvement in the commission and placement of art." 30

Despite this promising proposal, the AiPP was ignored by communities who were not interested in using artistic design as a method to form their neighborhoods. The plans for providing matching funding from the government relied heavily on the community to gather substantial funds to implement their artistic plans. ${ }^{31}$ Due to several discrepancies between the guidelines presented and communities' wishes, along with government

\footnotetext{
${ }^{29}$ Knight, Public Art, 36.

${ }^{30}$ Knight, Public Art, 15.

${ }^{31}$ Knight, Public Art, 16.
} 
control shifts, the NEA's AiPP program is no longer in effect. The idea of creating a community which shares interest in public art, however, continues through many city governments' Percent for Art Programs.

Many city governments created Percent for Art Programs that utilize a certain percentage of tax dollars to care for and contribute to the city's growing artworks. Ever since cities have started this program, artists have applied for the grants or contests sponsored by the city to install artwork in the city's local parks and public spaces. The city of Houston, for example, has an art program known as Houston Arts Alliance which is a group merged by the Cultural Arts Council Houston/Harris County, the Civic Art Committee, and the Municipal Art Commission. This group is responsible for the 1.75\% of qualified Capital Improvement Project monies that are specifically designated for civic art. "HAA serves as a unified entity to fund, advocate, preserve, [and] promote the arts in the Houston [and] Harris County region." ${ }^{32}$ Because of this group, the city’s three major parks and some smaller pocket parks throughout the city, contain works of art that range from historical statuary to contemporary works. Following the practices of museums and institutions who house art, several cities, including Houston, decided to reserve certain percentages of their art savings each year for conservation of art that is already installed. Preserving art and acquiring art makes an art-centered and growing cultural city.

Not all cities could afford or were willing to institute a Percent for Art Plan that seemingly detracted from other development projects. They attempted to find ways to provide art while being more cost efficient with government money. The city of Louisville, Kentucky, under the guidance of Creative Time, established a Public Art

32 “The City of Houston," last modified 2014, http://www.houstontx.gov/parks/artinparks/. 
Master Plan in 2010 that encourages funding from developers who are not restricted to contribute money in their own development site and without a strict percent requirement. Money can be shared with other companies through a funding pool for public art grants which would be allocated to 501(c)3 organizations through the Commission on Public Arts organization. ${ }^{33}$ This encourages local companies to be part of a larger public art project rather than selecting art for their own site, which is beneficial to forming a bonded community through art development.

As an important contributor to culture and identity, public art in parks seems to be a growing, progressive feature in cities. Concepts for public art include many different subjects comprised of many types of materials, temporal or permanent. Artists such as Patrick Dougherty install whimsical, temporal stick installations in many different public parks and places that act as shelter, playgrounds, and a catalyst for childhood memories. Or, artists such as Edward Hamilton utilize public sculptures to keep history alive. His work at Waterfront Park contains a series of bronze reliefs that illustrate the history of slavery and Abraham Lincoln's contribution to freedom.

Other public art work can be viewed at public art festivals. These events are temporal and last only a short amount of time such as one weekend or one night. Bernheim Arboretum and Research Forest hosts an evening event called CONNECT. This festival is a "collision of art, music, science and technology"34 around Lake Nevin. As described on their website, "artists, scientists, naturalists, progressive thinkers and

\footnotetext{
${ }^{33}$ Creative Time, "Louisville Public Art Master Plan," (Plan for city of Louisville's Public Art Committee, Louisville, Kentucky, June 2009), 12, http://www.louisvilleky.gov/NR/rdonlyres/6679C445-41E9-4A8A9272-3C195740761E/0/PublicArtMasterPlanoptimized.pdf.

${ }^{34}$ Ralph Bergmann, "CONNECT," Bernheim Arboretum and Research Forest, last modified August 24, 2013, bernheim.org/?s=connect+.
} 
innocent bystanders unite in this celebration of creativity and technology - informed, infused and surrounded by nature." ${ }^{35}$ This event, like many other temporal public art festivals, incorporates public art in a public space for one night - challenging the notion of public art as permanent and providing different effects for its audience.

Other artists are combining their urban planning talents with artistic design to refurbish abandoned spaces. Theaster Gates, an artist who is well-known for his repurposed public spaces, creates community projects that reflect the social sculpture concepts developed by Beuys. One of Gate's celebrated works is Dorchester Projects, located in Chicago. Gates purchased an abandoned home and refurbished it using recycled materials from the area to create a space for community and cultural interaction. The two story home became a library, slide collection and soul food kitchen. When his research indicated a records store previously existed in that location, it inspired him to provide an area where music could always be played in the home. People admire this project which is "both practical and poetic," as it "fosters neighborhood revitalization and serves as a model for greater cultural and socioeconomic renewal." ${ }^{36}$ Gates has inspired many emerging artists to evaluate the use of space as a gathering place that inspires community and culture.

Under the multiplying commissions from government committees, private businesses, temporal festivals, or community neighborhoods, art will continue to be an influential aspect of a public's daily life. As artists continue to expand public art technology, resources, materials, and creativity, a wider audience can be reached. The

\footnotetext{
35 "CONNECT."

36 "Dorchester Projects," Theaster Gates, accessed March 20, 2014, http://theastergates.com/section/117693_Dorchester_Projects.html.
} 
audiences who observe public art will become more diverse as public groups continue to expand their identities across the city. Through public art, the city publics can collaborate to become unified communities, benefitting the prosperity of the city and encouraging the public art field to challenge its audience with new ideas. 


\section{CHAPTER TWO}

\section{A BRIEF HISTORY OF ART IN GARDENS TO ART IN PUBLIC PARKS}

Since the biblical beginning of time, a garden has represented a place of goodness, beauty, and rest. Freedom from stress, work, and responsibility are commonly sought results from visiting gardens and parks. People have been inspired by garden design for centuries: “[o]ne might say that a nostalgia for the Garden of Eden has provided garden designers throughout history with a model of perfection to aspire to." ${ }^{37}$ It is only fitting that art, primarily through architecture, landscape design, and sculpture, was added to garden design to increase opportunities for mental and spiritual inspiration and relaxation.

Originally, parks were gardens created for private use. It wasn't until the $19^{\text {th }}$ century that cities in both Europe and the United States developed town squares with gardens or transformed private gardens into public ones. The urge to find a place in the city that resembled the peaceful and natural qualities of rural landscapes was strong: "...the idea of a garden...sprang from the recognition of the contrast that existed between rus and urbs, between the serenity and order of the rural world and the disorder of urban life." 38 A modern urban city continues to strive to create the experience of Adam and Eve

\footnotetext{
${ }^{37}$ Monique Mosser and Georges Teyssot, "Introduction: The Architecture of the Garden and Architecture in the Garden," in The Architecture of Western Gardens, edited by Monique Mosser and Georges Teyssot (Massachusetts: the MIT Press, 1991), 12.

${ }^{38}$ Lionello Puppi, "Nature and Artifice in the Sixteenth-Century Italian Garden," in The Architecture of Western Gardens, edited by Monique Mosser and Georges Teyssot (Massachusetts: the MIT Press, 1991), 47.
} 
by developing that piece of paradise it lost due to the constant development of buildings. The determination to find rus in urbs progressed throughout time to become the current example of an urban park. Characteristics of a contemporary urban park include places for rest, exercise, and community activities. In addition, aesthetic features of parks include landscape design, architecture, and art. "The garden, one of humanity's finest creations, has always endeavoured to combine the more homogenous and pleasing aspects of nature, often adapted to the wishes of man, with the highest form of art." ${ }^{\prime 39}$ Finding beauty in a city through a relationship between art and nature enables visitors the chance to learn about a city's culture, pride, community interests and methods for relaxation. Comfortable seating areas, welcoming walkways, well-developed community spaces, and public art are park benefits that provide opportunities for reflection, relaxation, and a united social network in a city.

Observation of garden progression from $16^{\text {th }}$ century Italy to city parks in France and eventually the United States, reveals that contemporary urban parks utilize and value traditional garden characteristics developed centuries ago. Often confined to small places (as compared to rural landscapes), an urban park is a place that is both an enclosure with borders and a place connected to some type of garden presenting "an image of paradise in the collective imagination." ${ }^{40}$ The limitations of the space requires public input, research, and collaboration to determine the best possible use of the green area provided. This is achievable as long as both the public who collaborates during the design and the public

\footnotetext{
${ }^{39}$ Mosser and Teyssot, "Introduction: The Architecture of the Garden and Architecture in the Garden," 12.

${ }^{40}$ Isabelle Auricoste, "Leisure Parks in Europe: Entertainment and Escapism," in The Architecture of Western Gardens, eds. Monique Mosser and Georges Teyssot (Massachusetts: the MIT Press, 1991), 483.
} 
who uses the space recognize the art in the park and the park as art. Strategic planning for landscape design prevalent during the Renaissance is the foundation for the strategic urban planning techniques used today.

Just as patrons of the arts focused on city development in $16^{\text {th }}$ century Italy, their wealth also paid for private villa gardens that contained art and architecture worthy of the owner's prestige. Even though these gardens were private, or rather only "public" to the owner's friends and relatives, the attention to design, botany, and choice of artwork became part of the stepping stones that developed into the modern public park. Three characteristics were certain to be found in a garden in the $16^{\text {th }}$ century Italy: the design element bosco ${ }^{41}$ use of water, and attention to perspective. All gardens contained varying amounts of these three characteristics depending on the garden owner's wealth. A garden that contained these three features enabled opportunities for visitors to rest and share intellectual discourse in the landscape setting. While the water and bosco features refer more specifically to the elements found in the garden design, the use of perspective involved the insertion of architecture and sculptural forms as points of interest.

The inclusion of bosco in a garden design was important to the element of surprise that was often valued by visitors. Bosco design was valued by owners whose land consisted of many trees. Large areas of woods allowed the natural aspects of nature to mix with the orderly designed aspects of the garden. ${ }^{42}$ (Figure 2.1) Visitors found it appealing to stroll along a heavily wooded pathway to "cultivated spots - paradise in the

\footnotetext{
${ }^{41}$ Bosco specifically refers to a garden that is heavily surrounded by woods or contains a substantial amount of wooded areas throughout the property.

${ }^{42}$ Terry Comito, "The Humanist Garden," in The Architecture of Western Gardens, edited by Monique Mosser and Georges Teyssot (Massachusetts: the MIT Press, 1991), 42.
} 


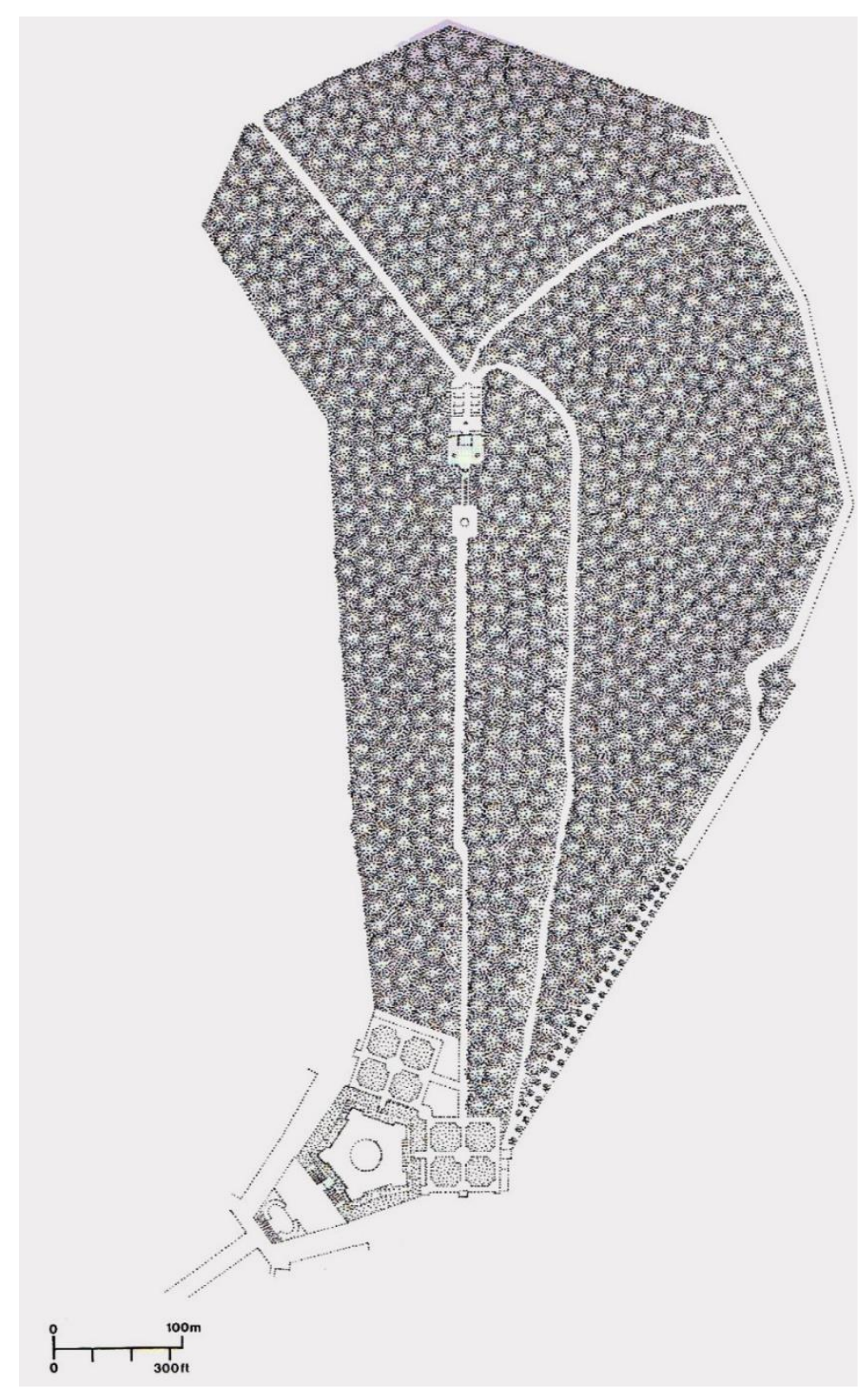

Figure 2.1. The gardens of the Villa Farnese and of the Casino, Caprarola: I General plan, after Lebas... This Garden map shows a heavily wooded garden design, emphasizing the value placed on bosco in the garden. See text for further information. 
midst of wilderness" ${ }^{\$ 3}$ where they could rest, converse, or eat a meal. The juxtaposition of natural woods and cultivated nature reveals an appreciation for the blending of natural elements and artistic design. Aesthetic enhancements in the cultivated areas in the woods often included a fountain or sculptures of garden nymphs.

In the beginning of the $16^{\text {th }}$ century, sculpture was purposefully not featured in the garden because the owner and gardener "sought to avoid detracting in any way from the purity of nature, or $r u s^{\prime 44}$ in the hopes that a harmonious relationship between the nature and owner would occur. Eventually, however, the number of water features were significant as an assertion of the garden owner's wealth. Abundant areas of water, including extended streams, fountain displays, and pools in both cultivated and uncultivated areas, signified a wealthy, noble family. Emphasis of water in the uncultivated areas, generally along the paths through the woods, often flowed around figural sculptures of nymphs and small grottoes. The subject matter of the art near water often involved animals such as turtles, dolphins, frogs and snails, or figural sculptures of goddesses and gods related to the earth or to the family who owned the garden. Fountain sculptures were adapted so that the figures' poses became purposeful to their intended scene. For example, water would burst forth from fallen vases, or drip from women ringing out their hair, or come forth from a mother's breast, and even shoot from the tips of weapons that the figures held. ${ }^{45}$ Eventually the water features would compete as some of the most elaborate sculpture work in the garden.

\footnotetext{
${ }^{43}$ Comito, "The Humanist Garden," 42.

${ }^{44}$ Puppi, "Nature and Artifice in the Sixteenth-Century Italian Garden," 49.

${ }^{45}$ Claudia Lazzaro, The Italian Renaissance Garden (New Haven \& London: Yale University Press, 1990), 132.
} 
Perspective in the garden, at this time, focused on the arrangement of plants and geometric rigidness of the garden landscape. The "Renaissance garden testifies to the nobility of its lord, of its city, of humanity in general" ${ }^{\prime 4}$ through the amount of land, inclusion of water, and convincing perspective which ties all features together. Perspective also revealed small areas for architecture, including grottoes and bench areas for rest. During this time "[a]rchitectural embellishment was certainly a popular means of ennobling the park landscape." ${ }^{47}$ The garden's design perspective generally led the visitor from the villa doors down terraces, through the gardens, and back to the villa doors by ways of right angled and straight paths. The perspective was broad, allowing the eye to travel across the entire garden, focusing on sections of the garden. As the century progressed, the integration of numerous artificial elements (art and architecture) and the shift from strict symmetric, geometric designs to looser versions of the same, altered the generic perspective points to narrowed focal points along the garden paths. These points of interest became sculptures, large fountain fixtures consisting of figural scenes or family crests, and private or hidden nooks along the pathways. Each focal point was designed as a destination spot for inspiration and rewarding discussion among garden visitors. The attention to detail went beyond the original garden designs, foreshadowing the future artistic endeavors that would emerge in gardens.

Sculptures still followed guidelines that declared their appropriateness in the garden. Garden sculptures were intended to provoke thought, aid in political or philosophical discussion, and bring artful design to the already aesthetic natural

\footnotetext{
${ }^{46}$ Comito, "The Humanist Garden," 41.

${ }^{47}$ Hilary A. Taylor, "Urban Public Parks, 1840-1900: Design and Meaning," The Garden History Society, Vol. 23, No. 2 (1995): 209, accessed January 6, 2014, http://jstor.org/stable/1587078
} 
environment. Some villa gardens contained figural sculptures of gods or goddesses whose stories shared qualities that related to the owners, or whose stories reflected a peaceful contentment with nature. Other gardens contained sculptures that portrayed symbols of the family crest. Many garden sculptures were thematically heavy on garden nymphs, or other creatures that exuded whimsical, lighthearted, and playful qualities. ${ }^{48}$ Often simplistic in form, each sculpture aided in the perspective of garden design and were functional in terms of their placement: as "the planting, subdivision of the garden, or source of water." ${ }^{49}$

Fountains and grottos were important to the concept of functional art. Fountain sculptures were the most prominent examples of a functional garden attraction. As mentioned above, fountain sculptures often connected the water flow to the fountain scene. Grottos were important to the perspective feature as their placement determined destination points along pathways. Built as areas for shade when resting, table areas for meals, and decorative covering over sculptures, grottos were an architectural embellishment to garden design.

The Medici family, a wealthy merchant family in Italy during the Renaissance, commissioned a garden that was no exception to the rule of rus as it utilized the three characteristics of a typical 16th century Italian garden. The Medici family's villa was elaborated with a grand garden that was based on "fundamental importance" 50 and revealed the wealth of the family. Traits common to the Renaissance style found in their garden at Villa Medici included straight pathways and right angles, geometrically shaped

\footnotetext{
${ }^{48}$ Lazzaro, The Italian Renaissance Garden, 131-132.

${ }^{49}$ Lazzaro, The Italian Renaissance Garden, 131.

${ }^{50}$ Puppi, "Nature and Artifice in the Sixteenth-Century Italian Garden," 47.
} 


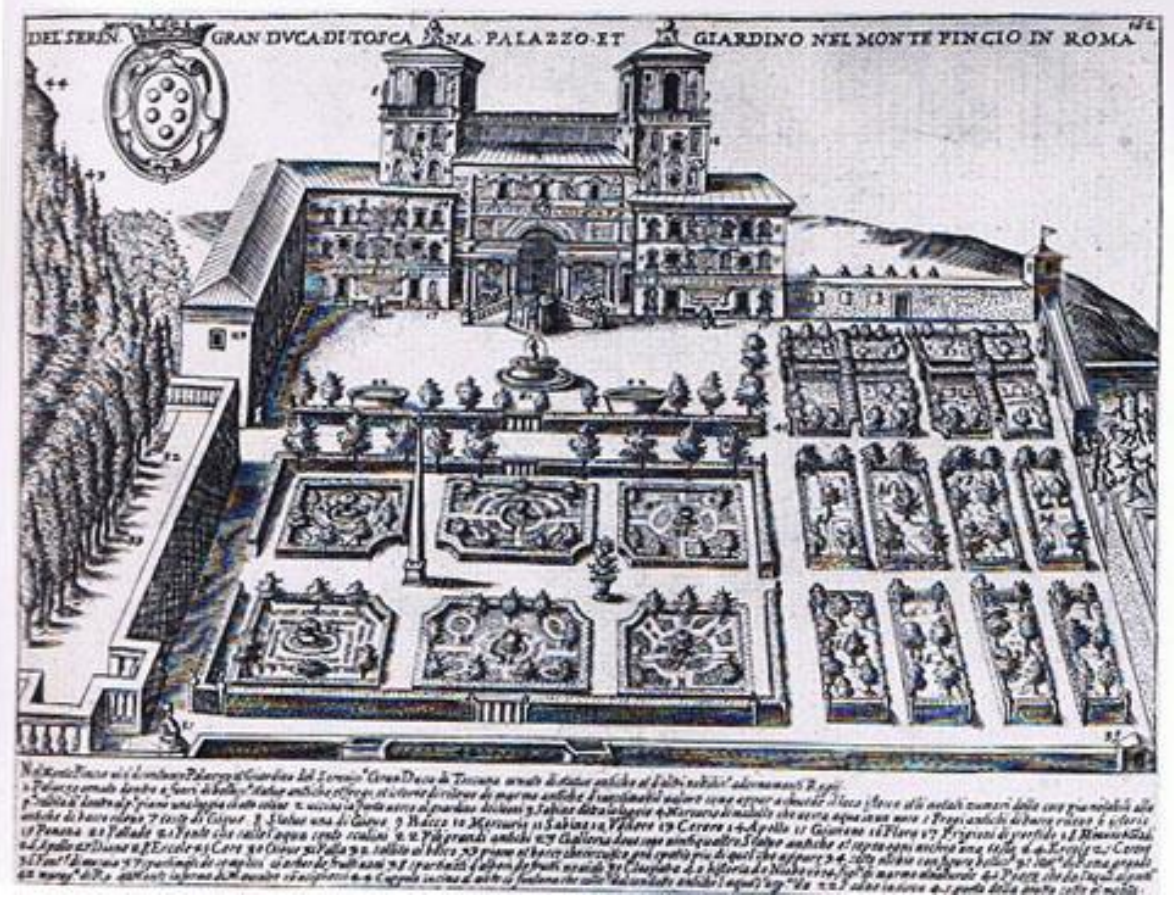

Figure 2.2. Villa Medici, Rome. From G. Lauro, Antiquae Urbis splendor, Rome 1612-14. Dumbarton Oaks, Washington DC. This illustration is an example of a villa garden that utilizes the three garden characteristics of an Italian Renaissance garden in the $16^{\text {th }}-17^{\text {th }}$ century.

garden areas that most likely displayed family crest sculptures and water fixtures within the garden squares. A water feature is illustrated near the estate entrance and a monumental pillar resides in the central area of the garden. Precisely planted trees seem to elaborate and provide shade along pathways (Figure 2.2). Water, bosco and perspective were all present in this design.

As the 17th century began, interests in botany declined as an interest in kinetic sculpture demanded attention in the garden. A new fascination with theater encouraged 'theatrical' sculptures as garden entertainment. The idea of a 'spectacle' for entertainment purposes can be found in some contemporary public art as well. Additions of many "artificial elements and ingenious technical devices of every conceivable kind" displayed 
the "wealth and privileges of their owner in every way possible." ${ }^{51}$ Garden design continued to focus on symmetry, however not as actively as it did in the past. The "view of the new gardens of the period was no longer simply to rule nature with geometry but to create an effect that was "pleasing and beautiful to the eye." ${ }^{\prime 52}$ More garden architects and designers entertained viewers with elements that went beyond the beauty of botany and into the realm of pleasure for the visitors. The incorporation of artificial objects such as kinetic sculptures and grotto galleries that housed objects of curiosity became essential to garden development.

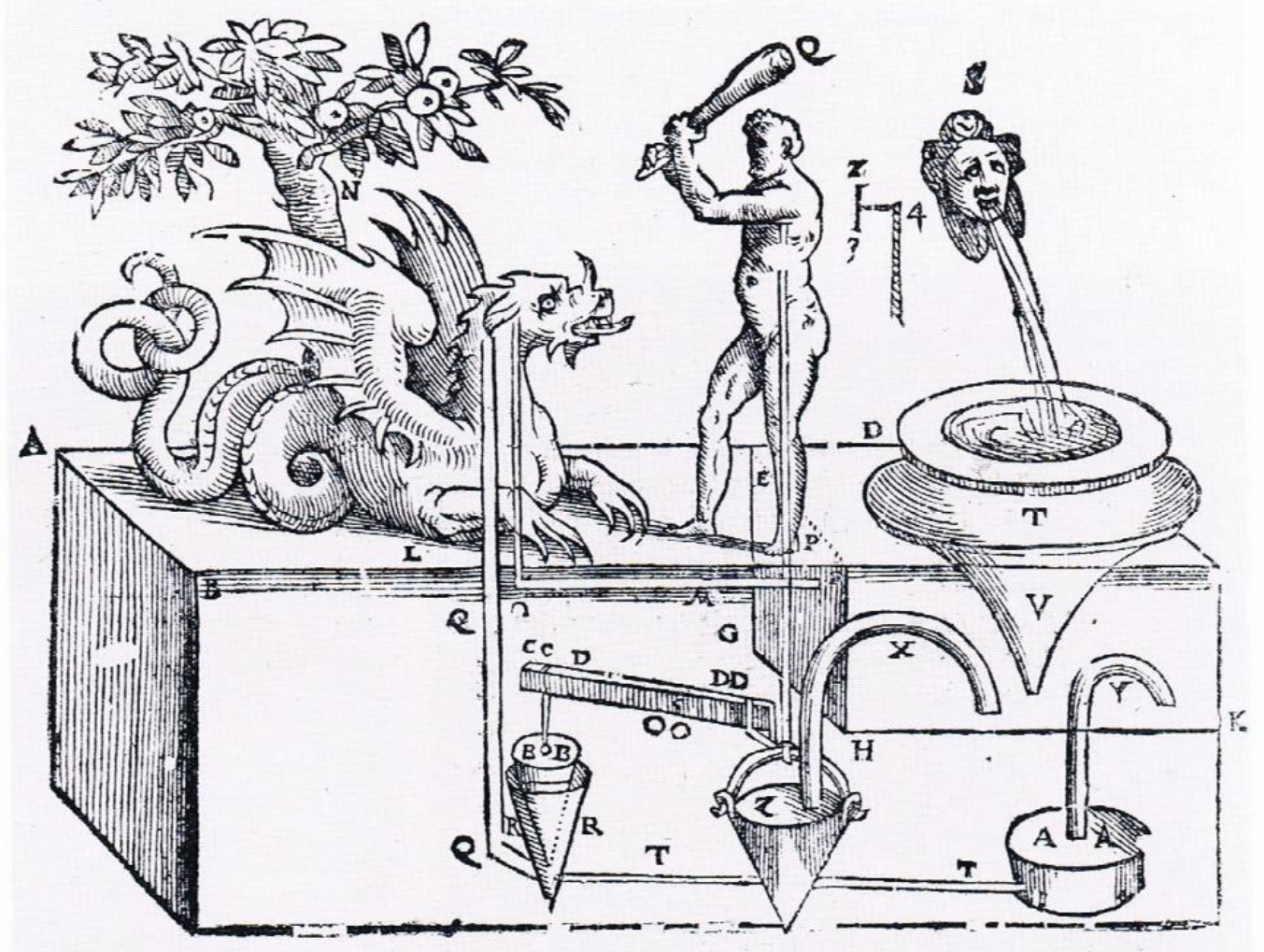

Figure 2.3. Hercules challenging the dragon that guards the golden apples: design for a mechanical theatre. Engraving by G.B. Aleotti, 1589. This illustration is an example of a kinetic sculptures that would be placed in a garden in the $17^{\text {th }}$ century. See text for further detail.

\footnotetext{
${ }^{51}$ Puppi, "Nature and Artifice in the Sixteenth-Century Italian Garden," 50.

${ }^{52}$ Puppi, "Nature and Artifice in the Sixteenth-Century Italian Garden," 49-50.
} 
Kinetic sculptures required the expertise of engineers, garden architects, and artists. This introduction of a professional public foreshadows the organizational component to contemporary urban park planning, however these parks were still privately enjoyed by owners and their guests. Through the use of pulley systems, waterpower engineering, and weight distribution methods, sculptures were installed throughout gardens to create small, theatrical scenes for visitors. These mechanical theaters were staged throughout gardens in grottoes and water features. Their placement was specific to the engineering systems that powered them. For example, a water fountain powered a kinetic sculpture through the weight distribution of the water that flowed underneath the fountain surface (Figure 2.3). This allowed the mechanics to remain unseen beneath the surface, but accessible in case of malfunction. This new delight for garden visitors became the early version of interactive sculpture. As the scene before them moved like theater, audience interaction and delight with the sculpture became more important in the garden environment than ever before.

The gardens surrounding the castle of Hellbrunn, in Salzburg, Germany, are the only remaining gardens constructed in the early 1600's that still operate with the original engineering systems for their sculptures today. Santino Solari was commissioned to create this garden in 1612. His engineered artworks include: a grotto tribute to Neptune with "groups of ornamental birds which sang - as they do today - by means of pneumatic bellows operated by water power," and a mask known as 'Germaul' located in the grotto, "which swiveled its eyes and stuck out its tongue." ${ }^{53}$ Further through the garden there

${ }^{53}$ Luigi Zangheri, "Curiosities and Marvels of the Sixteenth-Century Garden," in The Architecture of Western Gardens, eds. Monique Mosser and Georges Teyssot (Massachusetts: the MIT Press, 1991), 62. 
was also a water-powered cooler which could store food and drink and a marble table with "marble stools which played water jokes on unsuspecting visitors." ${ }^{2}$ Water jets connected different water pools, and grottoes containing theatrical scenes were prevalent throughout this garden. A visit to this garden became more than a place of rest and discussion, as it encouraged community interaction through the sculpture works.

In addition to the captivating mechanical sculptures, grotto galleries were also new attractions to gardens. Each grotto throughout the garden was decorated with exotic plants, rocks, and shells, or specifically housed unique objects such as the ones found at the Pisa Botanical Gardens, which included "the 'bones of a giant,' 'a piece of aloe wood six arms high and as thick as a man's leg,' and the 'tail of a sea-snake with the mouth of a serpent." $" 55$ Similar to the purposes of previous grotto spaces, these rarities or curiosities tried to provoke thought and discussion among visitors. Each object was part of the owner's collection, who willingly displayed them for his visitors and his own enjoyment when traversing the garden.

In 17 th and 18th century in France, attention to science and technology became an important part of garden development. Recognizing the garden as a work of art was a result of this collaborative effort to design a safe, well-planned garden space. Garden design involved land surveyors, engineers, architects, and gardeners who combined their talents to design successful garden spaces. "A garden is an artifice, and every artifice is characterized by a certain arrangement of its parts in relation to the whole, bearing in

${ }^{54}$ Zangheri, "Curiosities and Marvels of the Sixteenth-Century Garden," 62.

${ }^{55}$ Zangheri, "Curiosities and Marvels of the Sixteenth-Century Garden," 67. 
mind the desired end result. ${ }^{\prime 56}$ New technology was used to measure spaces, influence perspective, and engineer fountains and pathways throughout the garden. New tool inventions helped determine the measurements of proportional garden spaces (Figure 2.4). The community-involved aspect of many workers designing one garden relates strongly to urban park planning today. Public parks not only attract a public after its creation, but also involve a collaborative public during its creation. Again, this public is a professional public that is there to create rather than enjoy the garden space.

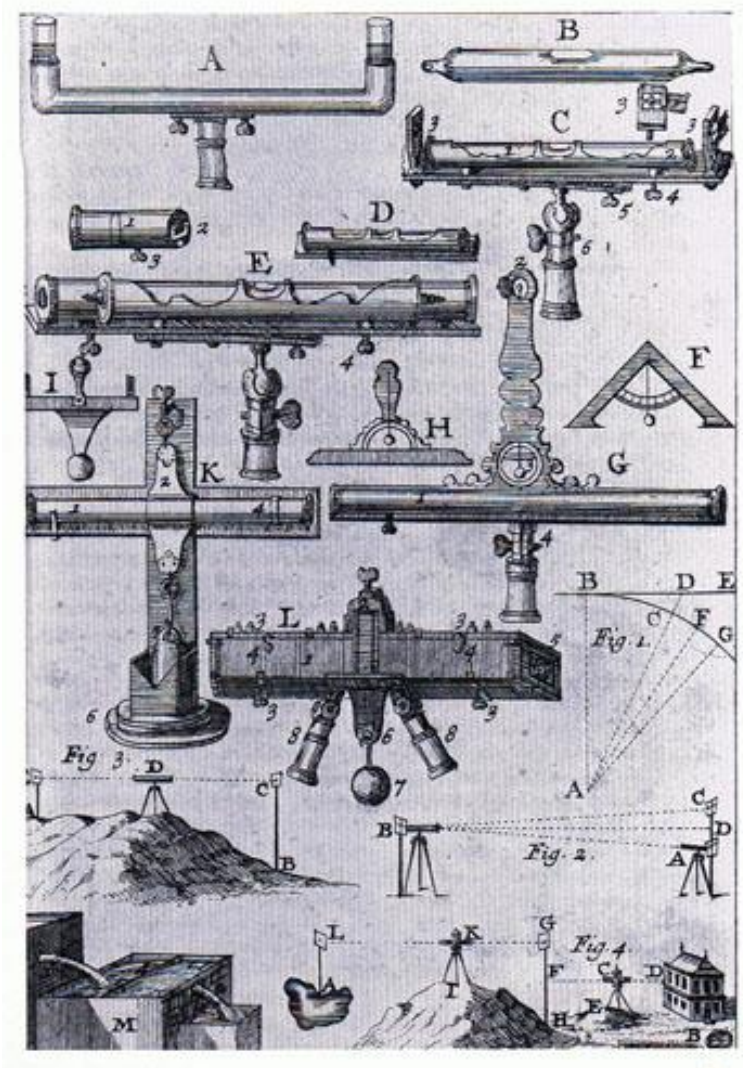

Figure 2.4. Levels and methods of levelling. From N. Bion, Traité de la construction...des instrumens mathématiques, Paris 1709. This illustration displays the many types of tools that were used for measuring the landscape. Even though most of the tools were not new inventions, their methods were new to landscape design.

\footnotetext{
${ }^{56}$ Hélèn Vérin, "Technology in the Park: Engineers and Gardeners in Seventeenth-Century France," in The Architecture of Western Gardens, eds. Monique Mosser and Georges Teyssot (Massachusetts: the MIT Press, 1991), 135.
} 
This was also the time that French citizens started the trend of public walks in gardens: “...urban walks and public gardens have for two hundred years been recognized as an essential element of French town planning." ${ }^{57}$ Many gardens became public, parklike areas that contained pathways that led to the woods on the outskirts of town or traveled along a water's edge, emphasizing the pleasure of the bosco effect while sharing an intentionally public atmosphere. These community parks displayed "the leisure activities of a well-organized community." ${ }^{58}$ A.D.F. Hamlin argues, "[n]o other people has succeeded so well in municipal gardening; in the art of embellishing the open spaces of a city's plan...in the laying out... of gardens and promenades for public use." ${ }^{59}$ These walks were a way for French citizens to see and be seen by others and encouraged city pride. Decorated with lavish arrays of plants, these garden squares lacked progressive garden development in terms of design and artificial objects; however, private gardens during this time continued to play with their themes of perspective and art in urban spaces.

Private gardens in urban areas continued to develop in France in the 18th century as places themed from a theater stage. Inspired by the theater's painted backdrops and framed scenes through the use of props and architecture, urban French gardens began to utilize architecture and sculptures as props for setting perspective. "These are theatrical contrivances and illusions, tricks of perspective which produce dramatic vistas in urban

\footnotetext{
${ }^{57}$ Daniel Rabreau, "Urban Walks in France in the Seventeenth and Eighteenth Centuries," in The Architecture of Western Gardens, eds. Monique Mosser and Georges Teyssot (Massachusetts: the MIT Press, 1991), 305.

${ }^{58}$ Rabreau, "Urban Walks in France in the Seventeenth and Eighteenth Centuries," 305.

${ }^{59}$ A.D.F. Hamlin, "Some Thoughts on Old World Gardens," Art and Progress, Vol. 5, No.7 (1914): 235, accessed January 6, 2014, http://jstor.org/stable/20561150.
} 
gardens in spite of their unremarkable size." ${ }^{60}$ Using "porticoes, colonnades, arbours, statues" 61 and other sculpture features, these small gardens were able to "give the illusion of unlimited space, ${ }^{\prime 62}$ which further emphasized the need for green space in the city environment. As seen in the engraving titled Le Parnasse francais, by Maisonneuve, this small park is enclosed with colonnades, windows for viewing the park at different angles,

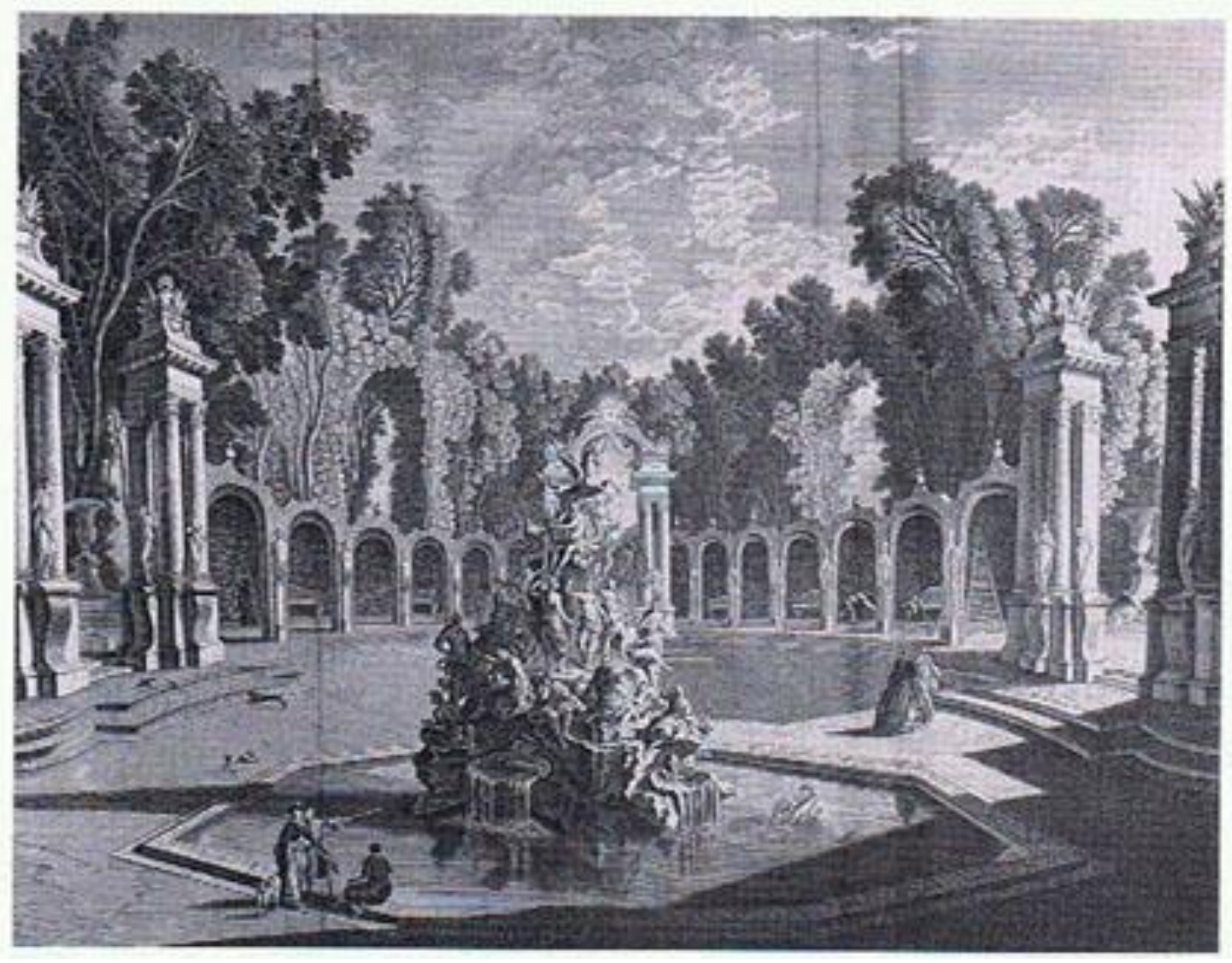

Figure 2.5. La Parnasse français, engraving by Maisonneuve, from a painting by Lajoue. Bibliothèque Nationale, Cabinet des Estampes, Paris. This engraving illustrates the use of colonnades, pillars, and statuary to create the illusion of amply space in a small setting.

\footnotetext{
${ }^{60}$ Marianne Roland Michel, "Scenography and Perspective in Eighteenth-Century French Gardens," in The Architecture of Western Gardens, eds. Monique Mosser and Georges Teyssot (Massachusetts: the MIT Press, 1991), 244.

${ }^{61}$ Michel, "Scenography and Perspective in Eighteenth-Century French Gardens," 244.

${ }^{62}$ Michel, "Scenography and Perspective in Eighteenth-Century French Gardens," 244.
} 
and a fountain as a central focus point (Figure 2.5). All of these aspects, among others, create an illusion of a larger space in a small setting.

It wasn't until the 19th century that parks became a growing feature in a city. Because city population increased during the late 18th century, the need for green space was important for the moral goodness and physical health of the people who lived in the city: "...the concept of a public park emerged as a response to problems of sanitation and urban growth." ${ }^{\text {63 }}$ Cities in Great Britain began to initiate government park projects, based on the examples from France which encouraged the idea that "central government should accept the responsibility for devising an overall design programme" ${ }^{94}$ for public parks. In 1833, the Select Committee on Public Walks and Places of Exercise prepared the first report before Parliament, discussing all the open spaces and possible locations for park development. After the British government began supplying funds for public parks, attention to artistic design declined as a park's functional properties emerged. ${ }^{65}$ The functional properties of parks thrived in areas concerning education, which became a primary focus for park development. Visitors had the opportunity to learn about the exotic plants and unique wildlife found in the park. The progression of art in the landscape and landscape design was neglected until later years.

A few decades after the British Parliament declared the need for public parks, the United States was developing its own municipal public parks due to the persistent advocacy of wealthy merchants and landowners of Manhattan ${ }^{66}$ who studied or visited

\footnotetext{
63 Alessandra Ponte, "Public Parks in Great Britain and the United States: From a 'Spirit of the Place' to a 'Spirit of Civilization,"' in The Architecture of Western Gardens, eds. Monique Mosser and Georges Teyssot (Massachusetts: the MIT Press, 1991), 373.

${ }^{64}$ Ponte, "Public Parks...,", 375.

${ }^{65}$ Ponte, "Public Parks...,", 376.

66 “Central Park.com,” accessed January 18, 2014, http://www.centralpark.com/guide/general-info.html.
} 
the city parks in Europe. Romantic architects Fredrick L. Olmstead and Calvert Vaux ${ }^{67}$ were the design team that established a plan for New York's Central Park in 1857, which incorporated rus in urbs characteristics through a design variation of wooded areas and open fields next to cultivated garden landscaping and lakes. As romantic architects, they utilized historical techniques and garden designs that included aspects of the natural landscape among organized nature. Olmstead appreciated the cultivated spots and Vaux enjoyed the natural areas. Between the two of them, one of the largest and most successful urban parks was created. Commonly known as a pleasure-ground, as its intentions were for leisure activities and relaxation, this park currently consists of 843 acres. Surrounded by city skyscrapers, it resembles a larger version of a garden square and contains many aspects adopted from an early version of a countryside villa in the 16 th century.

Artwork was not originally a part of Olmstead and Vaux's plan. Emphasis was placed on the decorative characteristics of nature which follows the early concepts of Renaissance gardens that limited the amount of sculpture in the space. Olmstead, specifically, felt that the park was a work of art on its own and did not need embellishment from artificial additions. ${ }^{68}$ When the park opened, however, commemorative statues representing Abraham Lincoln and Alexander Hamilton, for example, as well as other sculptures, were gifted to the park. Olmstead allowed them to be placed along the pathway known as the Mall. Eventually more artworks were commissioned to be placed in specific areas of the park. Even though Olmstead wanted

\footnotetext{
${ }^{67}$ Terence Young, "Modern Urban Parks," American Geographical Society, Vol. 85, No. 4 (1995): 537, accessed January 6, 2014, http://www.jstor.org/stable/215924.

${ }^{68}$ Miller, Central Park, 188-189.
} 
visitors to thrive in the art of the landscape only, "[t]he sculptures and monuments have played a central role in that process and contribute to the Park's status as a complex work of art." ${ }^{69}$ Now, people can traverse through the meadows and pathways to find a whimsical sculpture of Alice in Wonderland or a heroic sculpture of Balto. "Portions of Central Park...became the site of the Metropolitan Museum of Art..."70 which encouraged temporal work, environmental art and art from the Met's permanent collection to find ways into the park setting.

What is fascinating about the development of Central Park is that it focuses on one aspect of what makes it a public park: the public. "Central Park was a purpose-built people's park with an intended moral purpose growing out of, and reinforcing, American republican values." ${ }^{71}$ Since the beginning of its creation, the local government has continuously maintained the park in ways that provide leisure, activity and relaxation for visitors, which instills pride for the park and the city.

Since the construction of Central Park, other major cities began to develop their own park plans. Pleasure parks and eventually Reform Parks were created in areas across the United States. Pleasure parks are parks that consist of a designed landscape, green spaces full of plants, and artwork - Central Park is a prime example. Reform parks are much smaller parks located in neighborhoods and are intended for a quick retreat during the week. They are generally the size of a small lot on a neighborhood street where neighbors can visit, children can play on a playground, and community activities can take place. There is less green space, (perhaps more concrete if it was formerly a parking lot),

\footnotetext{
${ }^{69}$ Miller, Central Park, 189.

70 Terence Young, "Modern Urban Parks," 549.

${ }^{71}$ Miller, Central Park, 237.
} 
and typically few plants. Reform parks are focused on functionality while the pleasure parks act as a place for retreat. Unlike the pleasure park which was "quiet and serene, [a reform park] was noisy and organized, both visually and in terms of activity."72 The pleasure parks had curfews, and often closed at night, whereas "the focus of the reform park on organized activity led to its use during times when it would previously have gone unused." ${ }^{, 73}$ Nightly activities such as dancing lessons, and after-school activities for children were available at these locations. Reform parks would be closer to a person's home allowing a weekly visit, while a trip to Central Park, for example, would suffice as a weekend trip. ${ }^{74}$

No matter what type of park, art has made an entrance into park development as a necessary accompaniment throughout contemporary times. Landscape Architect Warren Byrd stated "There's a real hunger for these amenities in this context," when discussing the opening of Citygarden in St. Louis in 2009, after being surprised by the overwhelming positive interaction between city-dwellers and the artwork in the park. ${ }^{75}$ Interactive sculptures, such as Cloud Gate, by Anish Kapoor in Millennium Park, Chicago, Illinois, commemorative statues such as Sam Houston in Sam Houston Park, Houston, Texas, and environmental art such as South Cove by Mary Miss along Milwaukee's waterways, are all examples of art that currently exist in city parks today. A variety of types of art encourages everything from community interaction to

\footnotetext{
${ }^{72}$ Galen Cranz, "The Reform Park in United States (1900-1930)," in The Architecture of Western Gardens, eds. Monique Mosser and Georges Teyssot (Massachusetts: the MIT Press, 1991), 468.

${ }^{73}$ Cranz, "The Reform Park in United States (1900-1930)," 466.

${ }^{74}$ Cranz, "The Reform Park in United States (1900-1930)," 467.

${ }^{75}$ Architectural Record, "New Art Parks Enliven Urban Centers," accessed January 4, 2014, http://archrecord.construction.com/news/daily/archives/091001art_parks.asp.
} 
contemplation, resulting in a contemporary hybrid of pleasure and recreational park settings.

The influential artistic designs of the Italian Renaissance garden has continued to inspire gardens and parks throughout Europe and the United States throughout the centuries. Even with the adaptations, each contemporary park seeks to fulfill the needs of the owners and the needs of the citizens. Landscape design, as aesthetically pleasing as it is on its own, becomes more pleasurable to most visitors and landscape architects (with the exception of Olmstead and Vaux) with the addition of art, architecture, and spaces for community activities. Contemporary parks have adapted their characteristics using modern techniques that fulfill the same rus in urbs relief sought by people long ago. Public parks are shaped by a collaborative public for the public. A public park, full of natural and artificial elements, inspires visitors to play, rest, exercise, contemplate, and take pride in their community. 


\section{CHAPTER THREE}

\section{CONSTRUCTING A PUBLIC THROUGH URBAN PLANNING, NATURE, AND ARTISTIC DESIGN}

A public cannot be defined without its antonym private, especially when discussing a city public. ${ }^{76}$ People tend to be private by nature and demonstrate an inner need to remain separate when approached by others. Individuals are more likely to form a small public when people gather due to a common cause, activity, or group dynamic. Broader interactions also occur in a city that is well-designed for social experiences. A good example of a private public is a museum public. Museum visitors attend exhibitions because of a shared interest, yet their interpretations and observations of the artifacts are privately experienced in the public setting. This can also be true for a park public. For example, many people run in parks. These runners share a common exercise interest and perform it in a public setting, but the experience is uniquely individual. The personality of a city public relies heavily on the urban design surrounding them. A well-planned city encourages an integrated public developed from private experiences and opportunities. Just as ruling art patrons defined their audiences through art development, urban planners have the ability to provide opportunities for defining a public appropriate to a city.

\footnotetext{
76 This chapter discusses a city public, which, by my definition, is formed from smaller groups found within a city. These smaller groups include a park public and an art public, both of which are mentioned in this chapter.
} 
According to Google's definition, a public can be defined the following two ways as a noun: "ordinary people in general; the community," and "a section of the community having particular interest or connection." ${ }^{.77}$ Both definitions loosely define a group of individuals who share ideas, location, or a common culture, among other characteristics. A city public encompasses the interests of the sub-publics, which I define as a park public and an art public. Because the topic of this thesis is about the urban park public, a park public would reference any persons in the city who visit the park to exercise, rest, play, attend community events, observe art, and enjoy nature, among other park activities. A key component of an urban park, however, is that its intent was to be a space for the people who live and work in a city. Similar to the theory of "all parts make a whole" used in garden planning in $17^{\text {th }}-18^{\text {th }}$ century France, all types of public groups found in a city are what constitutes its identity as a city public. In order to understand a city public, it must be analyzed in parts. Specifically for the studies of urban public art in parks, these groups include a city, park, and art public. It is important to understand the methodologies and design practices of urban planners and local governments that aim to construct a lively public. A city public's behavior influences the direction for good urban design. Attention from urban planners and local governments is granted towards events organized by a city public (whether art, park, neighborhood, etc.), because such events reveal the dynamism of a city street or plaza which makes the event possible.

Common imagery associated with cities are streets with traffic, congested pedestrian walkways, scattered trash, cramped apartments, and concrete relieved by the

\footnotetext{
77 Google, "Definition of Public," accessed March 24, 2014, https://www.google.com/search?q=definition+of+public\&rlz=1C1CHFX_enUS552US552\&oq=definition+ of +public\&aqs=chrome..69i57j015.2329j0j7\&sourceid=chrome\&es_sm=93\&ie=UTF-8.
} 
random tree that seems inconveniently placed near the street. Even the inevitable thought of crime consumes the thoughts of many passers-by in areas that feel unsafe. Densely populated cities and competition for jobs increase the stress levels of many city publics. But, cities also promote job opportunities, night activities, adventure, and culture. Options for activities in a city are endless if the city is well-designed based on the public's needs and desires, rather than the government's or urban planners idea of design.

\section{Time use on an average work day for employed persons ages 25 to 54 with children}

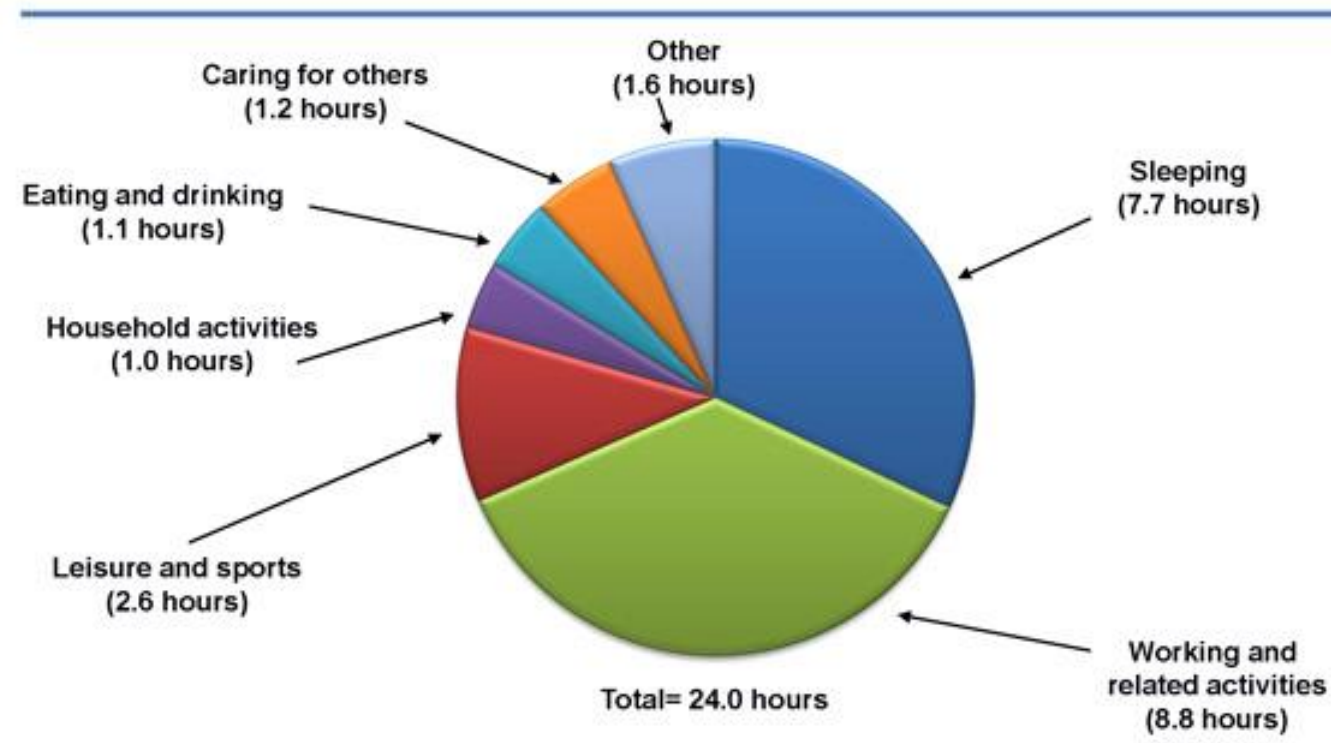

NOTE: Data include employed persons on days they worked, ages 25 to 54 , who lived in households with children under 18. Data include non-holiday weekdays and are annual averages for 2012. Data include related travel for each activity.

SOURCE: Bureau of Labor Statistics, American Time Use Survey

Figure 3.1. "Time Use on an average work day for employed persons ages 25 to 54 with children" This graph reveals the types of activities that take up a work day for the average person with children. Emphasis is placed on work and leisure and sports activities in the text.

According to the American Time Use Survey compiled by the United States'

Bureau of Labor Statistics, the average employed person from ages 25 to 54 spent 2.6 
hours in 2012 on leisure and sport activities and 8.8 hours on work or related work activities daily (Figure 3.1). This includes any sport or exercise activity and leisure activities such as watching TV, surfing the web, and spending time with friends (Figure 3.2). Specific studies that analyzed university and college-aged persons during the years of 2008-2012 revealed that the students spent a total of 3.4 hours on education activities and 2.7 hours on work or work-related activities daily. Their sports and leisure time averaged about 3.8 hours daily. ${ }^{78}$ From these results, it is evident that leisure and exercise activity (whether with a group or alone) is important to the daily routines of many people

\section{Time use on an average weekday for full-time university and college students}

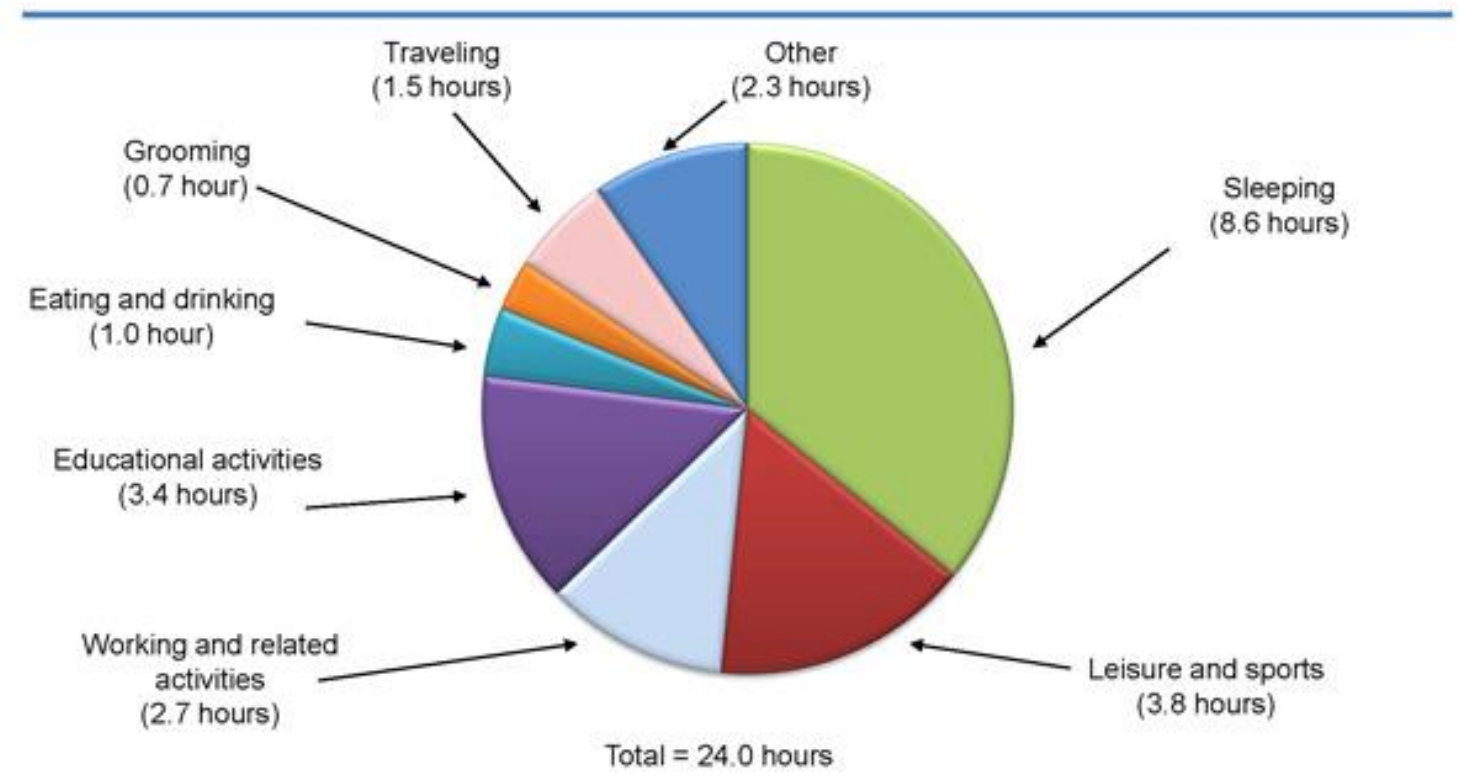

NOTE: Data include individuals, ages 15 to 49 , who were enrolled full time at a university or college. Data include non-holiday weekdays and are averages for $2008-12$.

SOURCE: Bureau of Labor Statistics, American Time Use Survey

Figure 3.2. "Time use on an average weekday for full-time university and college students" This graph illustrates the time use for an average weekday for a student. Emphasis is placed on work and related activities in addition to the leisure and sports section in the text.

\footnotetext{
78 “American Time Use Survey," Bureau of Labor Statistics United States Department of Labor, accessed February 12, 2014, http://www.bls.gov/tus/charts/.
} 
across the country. It is therefore important to provide opportunities and public spaces for individuals who wish to participate in sports, social and leisure activities where they live and work.

Signs that indicate a great city include activity, participants in activities, access to aesthetically pleasing public spaces, and community. These signs influence each other. Well-designed public spaces (open, inviting, safely constructed, and well-lit, etc.) promote more opportunities for activities, which encourage a social and lively public. The incorporation of art into such spaces creates a cultural dynamic among the lively public. A lively public creates strong city identity. But, because this chain-reaction begins with the space, it is important for urban planners to realize that a well-designed space is vital to creating a lively public.

Jan Gehl, architect and urban planner, discusses in his book Cities for People the many ways that cities have ignored the human population during development. Throughout this discussion, he provides examples that interpret and support a public's needs into urban design. Gehl states, "[n]either the city planners nor the traffic planners put city space and city life high on their agenda, and for years there was hardly any knowledge about how physical structures influence human behavior." ${ }^{" 79}$ His plans and observations put the people first in order to clearly present the concept that "caring for the people in the city is an important key for achieving a more lively, safe, sustainable and healthy cit[y]." ${ }^{80}$ His plan is comprised of three major subjects. These include four key objectives that create a better life for the human dimension of a city, provide an

\footnotetext{
${ }^{79}$ Jan Gehl, Cities for People (Washington, D.C.: Island Press, 2010), x.

${ }^{80}$ Gehl, Cities for People, $\mathrm{x}-\mathrm{xi}$.
} 
explanation for types of activities found in city life, and meet the needs for artistic elements in city design.

The following four objectives should be included in city planning in order to produce a good city public: liveliness, safety, sustainability, and health. Each of these objectives involves and influences the others. If the four characteristics are present, the city becomes a great place to live, and so we find Gehl saying, "[t]he potential for a lively city is strengthened when more people are invited to walk, bike and stay in city space." ${ }^{81}$ This invitation is derived from the amount of opportunities available for activity. The more opportunities for activity produces liveliness. When a city is livelier, more people are outside creating the feeling of safety. The more welcoming a space, the more likely a person is willing to live and entertain in that area. Similarly, activities - especially ones that include biking to work or walking to school - promote a "greener" city in terms of reducing the carbon footprint. Sustainability and attention to creating a cleaner environment is an attraction to a growing number of persons living in a city. Lastly, the more activities that promote biking, walking, running, and socializing create a healthier community physically and mentally. ${ }^{82}$ Therefore, all four characteristics, if followed and promoted correctly, inspire a community to be lively and welcoming to visitors.

Gehl's second topic explains the three types of activities found in a city: necessary, optional, and social. These three categories operate differently based on the amount of good and bad conditions in a city (Figure 3.3). Bad conditions include poorly designed sidewalks, un-safe structures, small and narrow community spaces, lack of

${ }^{81}$ Gehl, Cities for People, 6.

${ }^{82}$ Gehl, Cities for People, 6. 


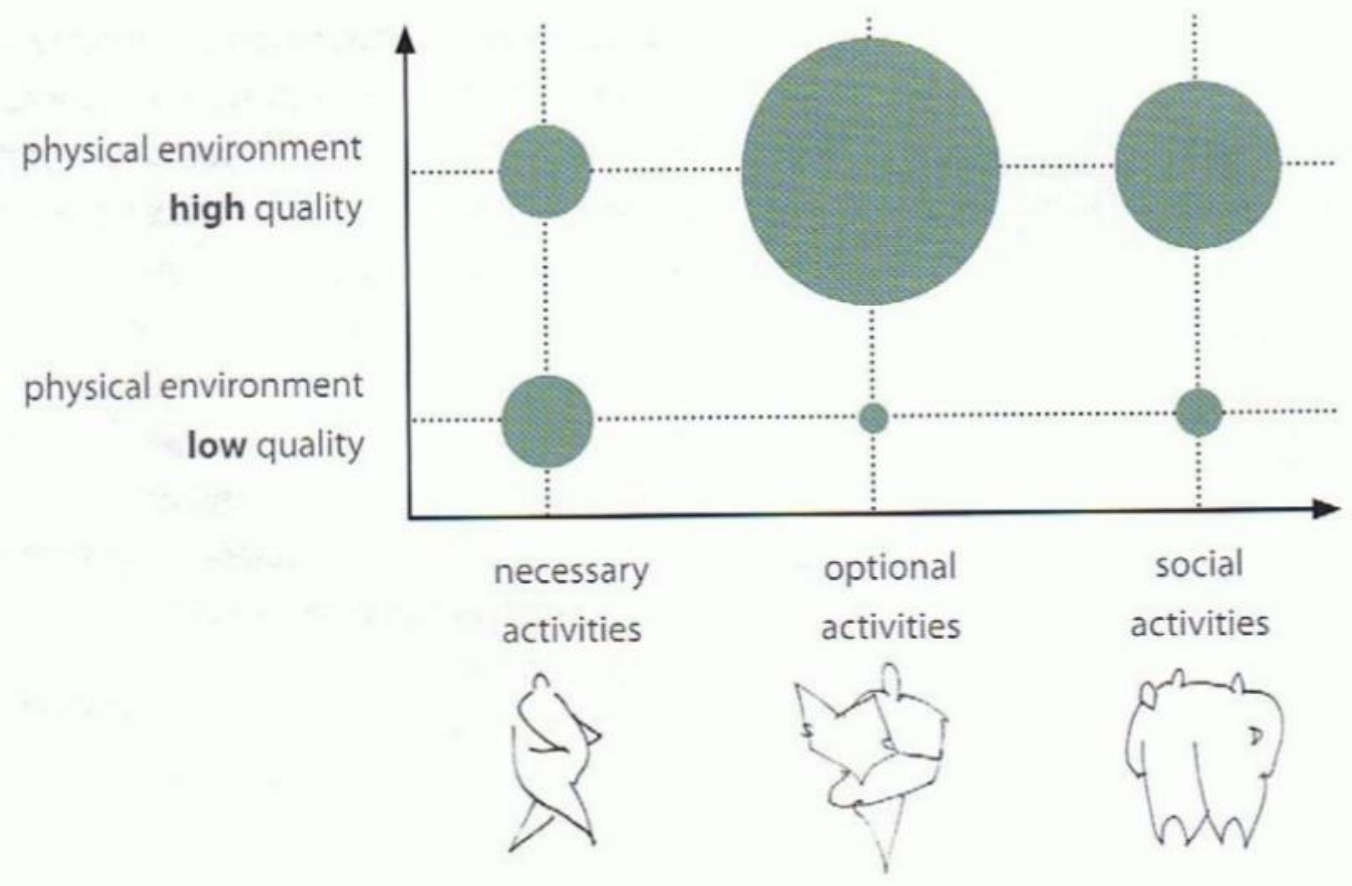

Figure 3.3. Jan Gehl's Condition vs. Activity Chart This chart, from Gehl's book titled Cities for People, explains how the conditions of the environment affect the activities (or social interaction) from the public. It indicates that the better the conditions, the more likely people will choose to engage with the public in the environment. See text for further explanation.

public spaces, and weather. Good conditions include open spaces, rest areas, safe building structures, well-planned walkways, and also weather.

Necessary activities are events that will occur in any condition. These activities include work and school. Optional activities are recreational opportunities provided by the city parks, public events, neighborhood events, and other places. These activities, such as dance classes at the park, a neighborhood baseball game, or book club at the public library, are all influenced by the conditions of a city. If there are worse conditions, including bad weather, people will choose to stay indoors and be blocked from social activity. Social activities are events that occur when the other two activities are in motion. These social activities can be as simple as waving hello to a neighbor across the street on 
the way to work or a friendly discussion at the bus stop. It also signifies a planned gathering at a park with close family and friends during leisure hours. ${ }^{83}$ More people are willing to interact with neighbors and attend public events when the city conditions are good.

Conditions also refer to the aesthetic design of a city. An aesthetically pleasing city provides spaces for people to interact and enjoy its environment. The functional qualities, good conditions, and artistic aspects of a city "must be interwoven into a convincing whole" 84 in order to create and encourage a public to interact with their environment. Art seeks to inspire good conditions as it represents the cultural identity of an audience in the city. It also seeks to make aware issues that are prevalent in contemporary society. Through these concepts, art strives to link communities together as a bonded public. Artistic design can be incorporated in walkways, stairwells, building lobbies, and most noticeably in public parks and public art.

Parks are the ultimate hosts in a city where the three types of activities, the four objectives, and the artistic embellishments of city design can be visualized. They are often redeveloped spaces funded by local government, where people can rest, play, walk to work, exercise, join a class, educate themselves on local history, observe art, relish in nature, and more. Contemporary urban park plans try to incorporate the best possible routes for sidewalks, trails, and bike paths, and the best spaces for playgrounds, waterparks, and amphitheaters among other features found in parks. They also try to make other areas accessible for voluntary exploration off the path. Parks are also known for promoting the health of their users.

${ }^{83}$ Gehl, Cities for People, 20.

${ }^{84}$ Gehl, Cities for People, 176. 
History teaches that urban parks developed in cities in the 1890s as a partial response to issues in overpopulation, over-worked citizens, increased crime rates, poor sanitation and misused city spaces. Eventually, park development included more recreation spaces, such as sports facilities, playgrounds, and waterparks, where visitors could play and interact with each other. Positive correlations between improved mental and physical health and green spaces in the city became known. "The health benefit of exposure to nature was an article of faith" 85 in the 1800 's. "Today those health benefits are being quantified, and scientific research is documenting the truth of what $19^{\text {th }}$-century planners believed." ${ }^{\prime 86}$ Local city governments continue to support funding for park spaces in urban areas because of the health benefits proven by recent surveys.

According to research conducted by Marc Berman at the University of Michigan, taking a 10 minute stroll through a neighborhood park during a work break produces positive cognitive results versus the typical coffee break at work. ${ }^{\mathbf{8 7}}$ "Even just looking at photos of nature in a quiet room has a greater cognitive boost than walking down a busy urban street." 88 Nature shifts a person's attention from something intensely focused (i.e. work) to something aesthetically calming without requiring focused attention. This freedom for the mind allows a person to release stress from work and daily decisions without requiring more work.

\footnotetext{
${ }^{85}$ Geoffrey Godbey, "Outdoor Recreation, Health, and Wellness: Understanding and Enhancing the Relationship," (paper prepared for the Outdoor Resources Review Group for Resources for the Future Background Study, Washington D.C., May 2009), 2.

${ }^{86}$ Godbey, "Outdoor Recreation," 2-3.

${ }^{87}$ J.Green, September 8, 2011, "Research Shows Nature Helps with Stress," The Dirt: Uniting the Built \& Natural Environments, accessed February 12, 2014, http://dirt.asla.org/2011/09/08/research-shows-naturehelps-with-stress/.

${ }^{88}$ J.Green, "Research Shows Nature Helps With Stress."
} 
Japanese medical field studies reveal the benefits of shinrin-yoku or "forest bathing" (a term coined by the Japanese Ministry of Agriculture, Forestry, and Fisheries in 1982) ${ }^{89}$ This study proved through medical testing that "the natural environment can enhance human health.."${ }^{90}$ In 2007, after all details of subjects, study sites, methods for physiological and psychological measurements, attention to physical environment factors, and experimental designs were composed, twelve participants were placed at a site that was almost equidistant between a forest and a city. Six participants were driven to the forest the first day, while the others were driven to the city. The task of every participant was to walk around. After certain periods of time, each participant had their pulse rate and blood pressure levels (among other tests) measured. The following day, the six participants switched locations and had the same tests performed. The study concluded "that walking in a nature reserve initially fosters blood pressure changes that indicate greater stress reduction than that afforded by walking in city surroundings." ${ }^{91}$ These results could amplify concerns for the amount of stress that not only walking, but living and working in a city, can amount to for an individual. Knowing this, some city officials are searching for ways to support programs for local parks because these places provide opportunities of stress release for the city public.

The Trust for Public Land's Annual City Data concluded in 2011 that out of the 22,493 city parks profiled in their survey, 62 million urban residents were participants in

\footnotetext{
${ }^{89}$ Bum Jin Park, Yuko Tsunetsugu, Tamami Kasetani, and Yoshifumi Miyazaki, "The physiological effects of Shinrin-yoku (taking in the forest atmosphere or forest bathing): evidence from field experiments in 24 forests across Japan," Environmental Health and Preventative Medicine 15:18-26, accessed February 9, 2014, doi: 10.1007/s12199-009-0086-9.

${ }^{90}$ Park, et al., "The physiological effects of Shinrin-yoku."

${ }^{91}$ Park, et al., "The physiological effects of Shinrin-yoku."
} 
park activities. ${ }^{92}$ This amount is equivalent to every 1 in 20 United States citizens. This participant number for parks continues to grow due to the population growth in cities and “[t]he demands of everyday life - commuting, work, complex decisions - [that] cause mental fatigue, a state characterized by inattentiveness, irritability, and impulsiveness."93 This issue of mental fatigue, in addition to evidence provided by medical studies, has encouraged "researchers and practitioners in health-related fields...to identify parks and recreation as a health service," 94 especially for children. The lack of outdoor activity for a child can cause "diminished use of the senses, attention difficulties, and higher rates of physical and emotional illness," known as nature deficit disorder. ${ }^{95}$ Evidence from park surveys also indicate the benefits of public parks.

Urban development strategies that promote a healthy, lively public involve survey research on and increased programming for parks. Public surveys indicate that the incorporation of “outdoor recreation into a city dweller's daily routines should be a priority." 96 Through the results of city surveys, city officials can determine important information about their citizens' needs. Results based on age groups can identify specific activities each group prefers. In the survey results conducted by Bureau of Labor Statistics across the United States, cities observed sport participation and exercise preferences in order to determine the park features that are most desired. Examples of these surveys are as follows.

\footnotetext{
92 The Trust for Public Land, “Annual City Parks Data Released by the Trust for Public Land," last modified December 8, 2011, http://www.tpl.org/media-room/annual-city-parks-data-released-trust-publicland.

${ }^{93}$ Godbey, "Outdoor Recreation," 4.

${ }^{94}$ Godbey, "Outdoor Recreation," 2.

${ }^{95}$ Godbey, "Outdoor Recreation," 9.

${ }^{96}$ Godbey, "Outdoor Recreation," 26.
} 


\section{Percent of people aged 15 years and older who engaged in sports or exercise activities on an average day, by specific activity, 2003-06}

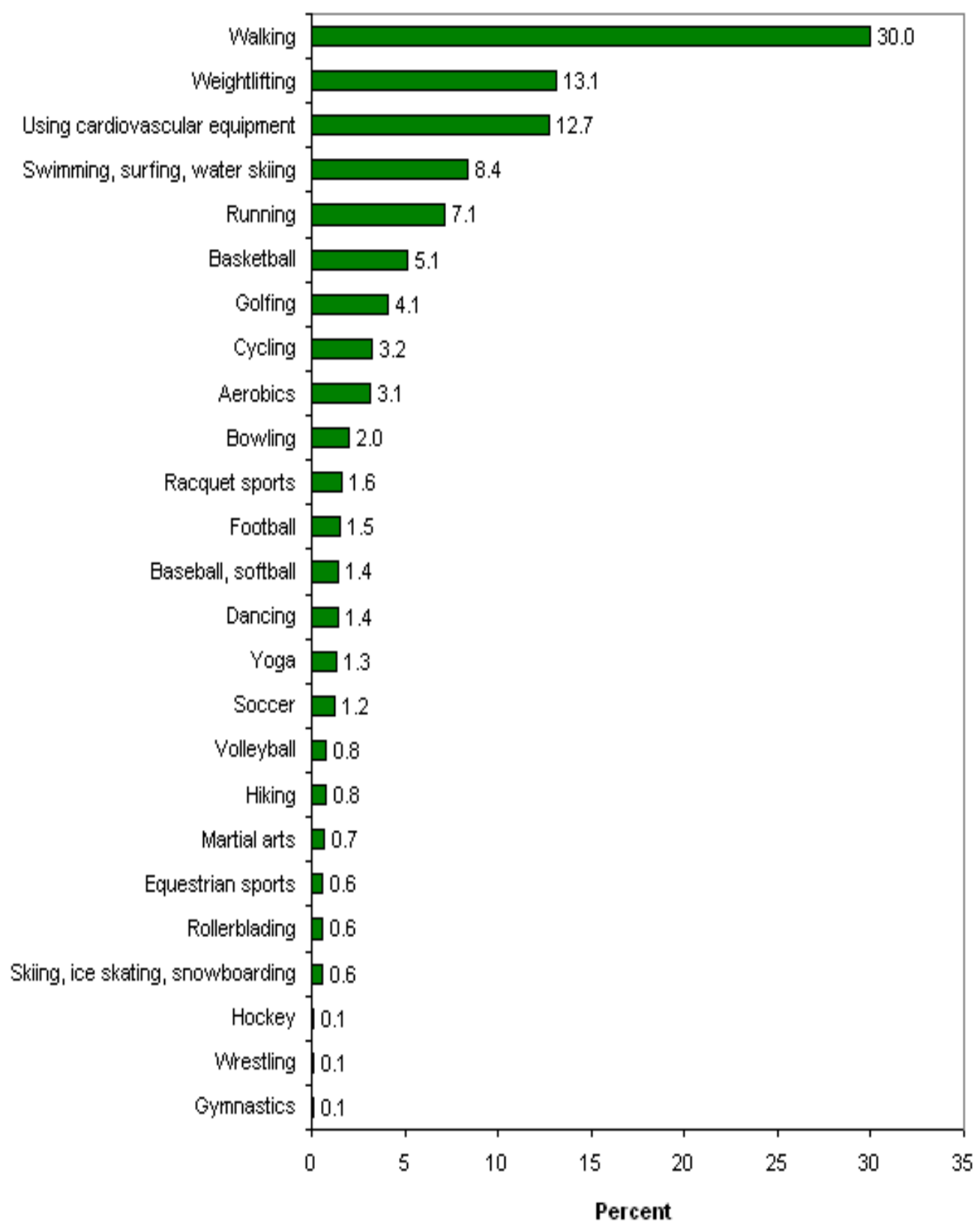

Figure 3.4. "Percent of people aged 15 years and older who engaged in sports or exercise activities on an average day" This chart reveals the recreational interests of United States citizens across the country. While it studies the recreational activities, the percentages are a hint at what local community and city parks should include in their recreational activities. See text for further detail. 
Percent distribution by age of people aged 15 years and older who engaged in sports or exercise activities on an average day, by activity, 2003-06

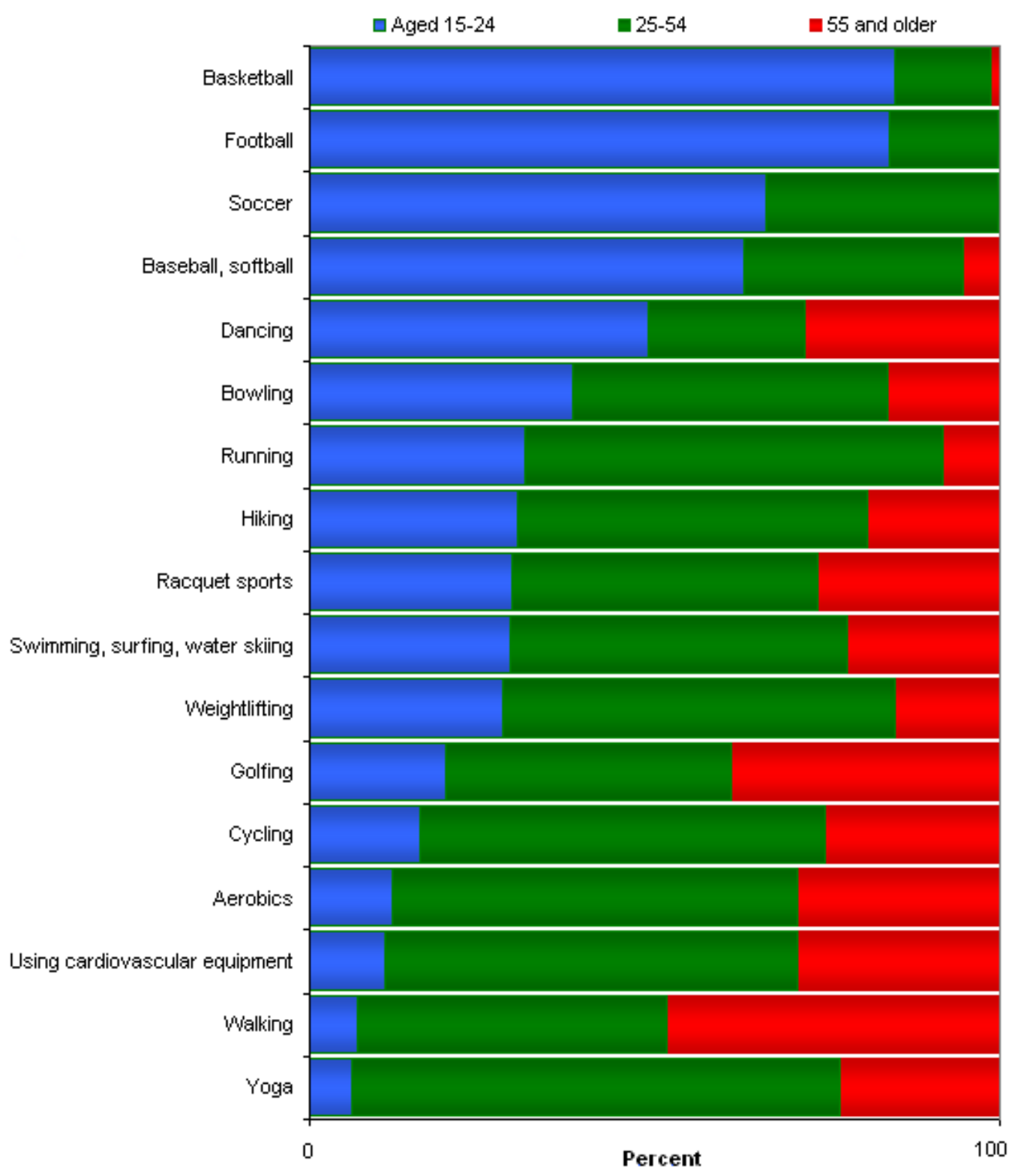

Figure 3.5. "Percent Distribution by age of people aged 15 years or older who engaged in sports or exercise activities on an average day" This chart reveals the percentage of recreational activities preferred by age group of citizens in the United States. This chart reveals the possible recreational interests for local community and city parks. 
The survey titled "Percent of people aged 15 years and older who engaged in sports or exercise activities on an average day" identifies the most participated sport for ages 15 and older (Figure 3.4).

The second survey, "Percent Distribution by age of people aged 15 years or older who engaged in sports or exercise activities on an average day," divides the age groups into three sections to reveal activity preference per age group (Figure 3.5). These charts are important for understanding the priorities of a park public. The results of each survey can determine what type of public program will be most successful. It can also indicate which areas of the park will require the most maintenance and can adjust budgets accordingly. Will Rogers, President of the Trust for Public Land, states, "Though budgets are tight everywhere, urban parks have consistently proven to be a wise investment, helping to improve health, increase environmental quality, and sustain property values... Parks are what make cities livable and attractive. ${ }^{" 97}$ Parks are considered to be a wise investment as they often monetarily increase land and residential areas which in turn encourages more people to move into the city near the parks.

City publics naturally like to engage in activity (as evident in the surveys provided), and good cities provide opportunities for such engagements. Parks that contain great walking paths, playgrounds, and community areas will enhance social and physical engagement opportunities. Gehl states that the city is a meeting place for citizens "where people have open access to express their happiness, sorrow, enthusiasm or anger at street parties, demonstrations, parades or meetings." ${ }^{98}$ Public parks increase the type of meeting

\footnotetext{
97 “Annual City Parks Data Released by the Trust for Public Land," http://www.tpl.org/media-room/annualcity-parks-data-released-trust-public-land.

${ }^{98}$ Gehl, Cities for People, 157.
} 
spaces available and, with the installation of art throughout the landscape, people can interact on a deeper level by chance in the art spaces.

Public art also makes cities livable and attractive. ${ }^{99}$ Art has made its way into the city environment to provide daily reminders that "beauty, monumentality, remembrance of important events, comments on life in society, fellow inhabitants, and city life, together with surprises and humor," 100 are important to the city space and the creation of relationships between art and people. Public art, as will be explained in Chapter Four, creates identities for cities and represents cultures found within each city. The art also connects cities together by portraying a global concept or a smaller engagement with nearby cultures and communities. ${ }^{101}$ Public art established city identity and culture by rallying the public on a broad subject, or by simply remaining a connection point for conversation. "Art has the power to reach across age, race, language, and class differences," by revealing contemporary concepts that try to connect people locally and globally.

Emphasis on cultural and art practices have been prevalent in United States public parks since the Philadelphia Fairmount Park Art Association incorporated public sculptures in parks in 1872. Since then, sculpture parks and parks with art have been developing across the United States. Recently, 100 Acres, The Virginia B Fairbanks Art \& Nature Park, part of Indianapolis Museum of Art, became such a park. This park provides the same opportunities of an art museum, only the work is outdoors, and

\footnotetext{
99 “Annual City Parks Data Released by the Trust for Public Land,” http://www.tpl.org/media-room/annualcity-parks-data-released-trust-public-land.

${ }^{100}$ Gehl, Cities for People, 179.

101 Jeremy Hunt and Jonathan Vickery, "Public Art in the $21^{\text {st }}$ Century," GROVE Art Online, accessed January 10, 2014, www.oxfordartonline.com.
} 
admission is free. Similar to a large public park, this park encourages "encounters with art that [are] sophisticated as any in the world," and "provide chance meetings with people from different walks of life." ${ }^{102}$ Lisa D. Freiman, Chair of IMA Department of Contemporary Art, explained that changing exhibitions are the leading reason guests make return visits to museums. With this in mind, she developed plans for the park that would "embrace the notion of change itself." 103 The artworks in this park were made by various artists who studied the landscape and integrated their work into the landscape settings. Some chose to place their work in the lake where it was untouchable to visitors, while others designed places for rest, or places to walk. "[The Park] provides a space for looking at art and also for experiencing it in relation to the distinctive environment in which it is enmeshed." 104 This park plays with the concept of garden perspective developed in the $16^{\text {th }}$ century by placing art throughout the landscape as destination points for visitors. There they can free their minds of daily stresses and perhaps have the transformative experience with art that museums often offer.

While art can instill peace in its viewers, a public can also react in negative ways to a work of art. The infamous Tilted Arc by Richard Serra, is a prime example of a work of art that received plenty of public attention - although negative. The work's placement in the center of a city pavilion disrupted the experiences of daily visitors, and thus

\footnotetext{
${ }^{102}$ Maxwell L Anderson, foreword to 100 Acres, The Virginia Fairbank Art \& Nature Park, ed. Marlon Blackwell (Indianapolis: Indianapolis Museum of Art, 2010), [no page number].

${ }^{103}$ Lisa D. Freiman, "100 Acres: A Living Sculpture Park for the $21^{\text {st }}$ Century," in 100 Acres, The Virginia Fairbank Art \& Nature Park, ed. Marlon Blackwell (Indianapolis: Indianapolis Museum of Art, 2010), [no page number].

104 "A History of 100 Acres: The Virginia B Fairbank Art \& Nature Park," in 100 Acres, The Virginia Fairbank Art \& Nature Park, ed. Marlon Blackwell (Indianapolis: Indianapolis Museum of Art, 2010), [no page number].
} 
resulted in the removal of the work. ${ }^{105}$ Research and specific placement of artwork is important to the outcome of the artistic qualities of urban design, the social structure of art supporters, and the economic exposures to underdeveloped city areas such as the plaza where Tilted Arc was installed.

Art and parks have always shared a cultural relationship. This relationship originated with music and parades in park squares, and eventually many types of art temporal, commemorative, film, dance, theater, and even museums or art education spaces - made their way into the city park landscape. The American Planning Association describes four key points of how cities use parks as places for artistic and cultural experiences. First, as mentioned previously, cities create parks as spaces for activity. These types of activities are not limited to physical exercise but also involve artistic events and festivals. Second, parks can create community bonds with artists and creators. Free art classes or contests for murals are only two examples of many ways that this relationship can occur. Third, artistic programming plays an important role in the revitalization of a park. Hosting evening art or cultural events can prevent the fear of being at the park at night because crowds often encourage participation. Fourth, art events and projects can draw new audiences to the park, enhancing the resources provided to the city public. ${ }^{106}$ These four points are similar to Gehl's key objectives. Engaging the city public with art in their local parks can strengthen community culture - especially if the community was involved in the designing of the project themselves. The art can carry an "afterlife" aspect which ties community generations

\footnotetext{
${ }^{105}$ Hilde Hein, "What is public art? Time, Place, and Meaning," The Journal of Aesthetics and Art Criticism, Vol. 54, No. 1 (1996): 1-7, accessed January 6, 2014, http://www.jstor.org/stable/431675.

106 "How Cities Use Parks for... Art and Cultural Programs," American Planning Association, last modified 2013, http:// www.planning.org/cityparks/briefingpapers/arts.htm.
} 
together as long as the works are maintained. ${ }^{107}$ This "afterlife" characteristic aids the memorial aspect of many types of art. Art also aids in the idea of reducing stress and creating a pleasing image: "as you view the art: "your progress through the space is slowed down." "108 Therefore, art carries an individual impact and group impact in the green city spaces.

For a city to be considered "great" it relies heavily on its structure created through urban planning to form an integrated lively and attractive public. Ideas for constructing such a lively city public should include consideration of Jan Gehl's four key objectives and understand the types of activities associated with good and bad conditions in the city. Public park spaces and public art, which are included in the aesthetic conditions of a city, are now considered health benefits for the community and are highly encouraged across the United States. Local city governments are searching for financial support to implement park and public art development and maintenance for both, so that their city public grows and remains healthy, relaxed, and welcoming to visitors and citizens. Every city public is comprised of parts, including recreational, park, and art publics. Each part is integral to the outcome of a city public as a whole. If public spaces follow guidelines that put consideration of the needs and desires of the public first, then all public niches have the opportunity to come together to form a lively whole. A unified public creates a strong city identity. A livable and attractive city includes a lively and healthy public realm.

\footnotetext{
107 J.Green, October 15, 2012, "Why Public Art is Important," The Dirt: Uniting the Built and Natural Environments, accessed February 13, 2014, http://dirt.asla.org/2012/10/15/why-public-art-is-important/. 108 J.Green, "Why Public Art Is Important," accessed February 13, 2014.
} 


\section{CHAPTER FOUR}

\section{CONTEMPORARY ISSUES CONCERNING PUBLIC ART: THE PUBLIC, EVALUATION, AND CONSERVATION}

Popular images of a bronze statue or stone carving come to mind when hearing the words public art. However, the range of tangible and intangible features of contemporary public art more strongly include permanent, temporal, environmental, landscape design, political, social, and technologically advanced characteristics than seen before. Advanced public art genres require thorough research that determines specific placement of the work and the possible public it will construct. It also requires advanced maintenance techniques for conservation practices and useful methods of critical evaluations. These three topics have all presented challenges for contemporary art practices and are prevalent during the development of the project, its establishment into the site, and in the evaluation results indicating social impact. Even though several websites and published writings share the critical issues about contemporary public art, few have proposed solutions to the issues.

After an artwork is properly installed, it is at the mercy of the public. Public reaction can include outrage, delight, misinterpretation, ignorance, pride, political posturing, and more. Reactions can also entail physical responses such as natural points of congregation and socializing such as a playground that is well-used or vandalism which has been a reaction to architecture and cultural symbols for centuries. As far as 
content goes in a work of public art, "no subject is safe from retribution."109 This is especially true as it has been known that people do not always wish to read about the artwork or learn beyond what they see visually in a work of art. Just as urban planner Jan Gehl uses a humanist approach when designing a city, so should artists and art producers when preparing to install a work of art. Thorough research regarding the history of a city and the specific site of installment is vital to the predicted reaction and acceptance by the public. However, even thorough research does not predict unanticipated reactions which can be seen as expressions of diversity, liveliness, and openness if received and accommodated with thoughtful response. Not only does the installation of public art in a city construct a space, it also constructs a public. Significant research detailing the city's history and plans for educating the public about the artwork are crucial for the success and support from the public.

As mentioned in Chapter Three, public art has the opportunity to reach across continents with its message or address issues that relate to a public locally. For example, new advances in public art strategy - rapidly evolved to reach out to the public with more demanding challenges to tradition - include temporal works. The fleeting characteristics of temporal works mimic the fast pace of society. Kirstin Van Cleef, manager of temporary art projects in Scottsdale, Arizona, says that "momentum is key in nurturing the public's appreciation for temporary public art... the art is hip and transitory, and it has to exude a 'catch it while you can' attitude."110 The city of Phoenix, Arizona embraces temporal public art and often promote temporal works that encourage social

\footnotetext{
${ }^{109}$ Steven Goss, "The Problems with Public Art: Does the Public Like Its Art?" accessed February 10, 2014, http://theapesheet.com/archivesix/public/html.

${ }^{110}$ Deborah Ross, "Temporary public art is rising in Phoenix - in myriad forms," Art Ltd., Jan/Feb 2014, 40.
} 
impact. Recently, artist Ann Morton turned a vacant lot into a giant, blanket-covered public square. These multi-colored blankets resembled a pixelated view of desert flowers from a birds-eye view. After its two day exhibit, the 300 blankets were separated and given as a donation to the homeless people living in that area. This work transcends city boundaries by seeking to speak about a global social issue of homelessness even though the project focuses on a specific area in the city of Phoenix.

An example of a work of art that reaches a broader, national audience is the "Vietnam Memorial" by Maya Lin in Washington D.C. This permanent work remains iconic in the public's eye years after its installation. Made of gabbro rock, this slice in the hill acts as a reverent reminder of United States history. Even broader still, art such as "The Thinker" by Auguste Rodin, remains valuable in its iconic sense as it transcends country boundaries and is recognized as significant artwork worldwide.

The environment has important impact on a public's daily activities, which explains why many cities are commissioning artists to design local urban parks and artwork in the park. Similar to the idea of garden designs from the late Renaissance period to the $18^{\text {th }}$ century French city gardens, artists are contributing their artistic design in park plans for the city. These plans retain the functional features of parks while incorporating artwork in the landscape. This prevents the usual mistake of "plop art" (art that was not properly researched and does not fit into its environment) as it increases aesthetic and functional natural areas for city dwellers. The "High Line" in New York is an excellent example of an environmentally friendly, well-designed work of art that encompasses nature and refurbishes an abandoned transportation route. Rather than destroying a built structure, this project worked with the rail line to provide a walkway 
above the streets in the city. Blending nature with city construction, the "High Line" has become a habitat for birds and a peaceful environment/pedestrian route for tourists and city dwellers. As studies have revealed, nature and artistic design in urban environments reduce stress and promote better health. The High Line has also increased the economic value of living in that area because, as Gehl's studies reveal, artistic design in city planning places a higher value on living spaces.

As mentioned previously, constructing a public through art requires ample research concerning placement. Placement requires specific expenses, influences people's reactions, and promotes or demotes the art as an icon for the city. When a public work of art is placed in a poorly designed setting, expenses are wasted as the work often is abandoned. "For public art as art to work it must be visible," otherwise it is comparable “to that of familiar works in a museum's permanent collection, which go unnoticed unless they are rearranged or moved to an unfamiliar place."111 To save time and cost, the placement of public art must be researched thoroughly to prevent the relocation process of the art. Research is also "integral to the process of finding lines of communication with a 'public.""112 Proper research guides the artist into a conceptual direction that their commissioner and audience will enjoy.

An example of a work of art that failed in terms of its placement was Tilted Arc created by Richard Serra in 1981. This work was placed down the middle of a public square. The intention of this giant slab of steel was to block the view from the street to the courthouse and vice versa so that "the space would be understood primarily as a

\footnotetext{
${ }^{111}$ Harriet F. Senie, "Responsible Criticism: Evaluating Public Art," Sculpture Vol.22 No.10 (2003), accessed February 15, 2014, http://www.sculpture.org/documents/scmag03/dec03/senie/senie.shtml. 112 Hunt and Vickery, "Public Art in the $21^{\text {st }}$ Century," www.oxfordartonline.com.
} 
function of the sculpture." ${ }^{113}$ Serra wanted to activate the space of the bland public square. Very soon after however, this work was considered to be "visually offensive, that it disrupted the use of the plaza for recreational events, and that is posed an unacceptable security risk." ${ }^{114}$ His work was removed in 1985 after a series of public hearings. Even though the outcome of this trial issued the work's removal, it has brought attention to how much public art influences social reaction and interaction. It will serve as a reminder for future public artworks to provide some effort "to develop a language - either in the art or its explication - that is intelligible to at least some of those unfamiliar with contemporary art," ${ }^{115}$ in order to close the gap between the art community and city public.

Another example of a public's scorn to artistic development in a city space relates to Cincinnati's role in the $19^{\text {th }}$ century as one of the largest meat-packing industries. Artists incorporated aspects of this history into the bridge and park designs along the Ohio River. Andrew Leicester's Cincinnati Gateway in Sawyer Park included four pigs with wings at the top of the gates. "Certain present-day Cincinnatians felt that Leicester's winged pigs were a joke at their expense," 116 as they did not wish for pigs to become the symbol of the city again. However, other citizens were enthralled with the idea and relished in the history of the city by rallying "pro-pig" during a public hearing with the city council about the design, bringing two live pigs who presumably supported the

\footnotetext{
${ }^{113}$ John Beardsley, Earthworks and Beyond: Fourth Edition (New York: Abbeville Press, 2006), 128.

${ }^{114}$ Beardsley, Earthworks and Beyond: Fourth Edition, 128.

${ }^{115}$ Beardsley, Earthworks and Beyond: Fourth Edition, 129.

${ }^{116}$ Beardsley, Earthworks and Beyond: Fourth Edition, 148.
} 
project. ${ }^{117}$ The pig enthusiasts won the hearing and the design was incorporated into the city park.

Such enthusiasts promote the favored works of public art as icons for their city. St. Louis arch, for example remains known as the Gateway to the West. Or in Grand Rapids, Michigan, a public reacted to an artist, David Dodde, who attached magnetic, unharmful, floral pieces to an Alexander Calder work in their city during a time-limited contest. Most people were upset with the installation because it disrupted the normal appearance of an iconic sculpture that the town was proud of and it altered the original intentions of Calder's art. Dodde was disappointed, however, he stated in an interview: "I know that I've ruffled a few feathers and that's art. Art makes people uncomfortable... so I gotta say I was successful and I felt successful the minute it went up." ${ }^{118}$ Dodde, however, seems to neglect notions of his overall goal (i.e. winning the contest with his concept and sculpture) which may undermine his artwork's original intent, ultimately signifying his accepted defeat within the competition.

Sometimes, however, the placement of the work followed the history of the site and the supposed pride of the community, but there is a barrier concerning a community's knowledge about contemporary art. The second issue concerning contemporary public art is education, or lack thereof. This educational issue is important because if public art contributes to a city's community identity, cultural values, and creates a unified public, it would be helpful if it were understood correctly. Research shows that "cities with an active and dynamic cultural scene are more attractive to

\footnotetext{
${ }^{117}$ Beardsley, Earthworks and Beyond: Fourth Edition, 148.

${ }^{118}$ Katherine Brooks, "Don't Mess with Our Alexander Calder, Says Michigan Town," Huffpost: Arts \& Culture, September 26, 2013, accessed November 13, 2013, www.huffingtonpost.com/2013/09/26/daviddodde_n_3995925.html.
} 
individuals and businesses." ${ }^{\prime 19}$ Without educational opportunities, iconic artworks such as the ones mentioned above, would become abused, neglected, or misused by the public.

In a series of interviews random people were asked several questions related to public art, one being: Does public art offend you? Two responses revealed that the individual misinterpreted the art which affected their knowledge about the work. The first interviewee, for example, responded to the question by stating, "Once I was in Ontario and I saw this statue of a penis, only it wasn't a penis. It was a statue of John Macdonald but from a distance it looked like a penis. If it had been a penis I would've probably been upset." ${ }^{120}$ Clearly, this statue of John Macdonal in the mind of this individual will forever remind him of a phallic symbol, supplanting the real reason the statue exists, which seems to be a tribute to a political leader. The second interviewee tied racial issues into their misinterpretation when responding to the issues by stating that the work of art wasn't neutral enough. "I loved the CowParade series in the city this summer. But I was a little bothered by the cow that had the afro and looked black. Not that I am black or anything, but people should be more sensitive." ${ }^{121}$ She immediately assumed that a cow wearing an afro was a racial insult without referencing who the artist was, or the setting in which the cow was placed. Both of those aspects of a work of public art are clues to the purpose of the work, but those context clues are ignored. This is how alternative impressions and meanings arise from the same work of art.

This misinterpretation issue is a critical problem for contemporary public art in urban parks. Anish Kapoor's "Cloud Gate” in Millennium Park, Chicago - known as

\footnotetext{
${ }^{119}$ Americans for the Arts Blog, "Why Public Art Matters," Public Art Network Council: Green Paper, blog.artsusa.org/category/public-art-greenpaper/.

120 Goss, "The Problems with Public Art..."

${ }^{121}$ Goss, "The Problems with Public Art..."
} 
"The Bean" to the artistically misinformed public - "embodies one principle of public art: the public can appreciate art so long as they misunderstand it." 122 From a city politician's standpoint, "Cloud Gate" is an ideal form of public art because it is "for everybody, it is a centerpiece of the city, huge numbers of people interact with and enjoy it." ${ }^{123}$ But, to the artist, this may not be the response that was originally intended. While the artist's opinion, particularly in this case, does not outweigh the public's opinion of the work, this example can act as a reminder to other artists to make sure their concepts are accessible to their audience.

These examples of misinterpreted art are only a few among many misinterpreted works across the globe. When people tour a city or explore the parks of a city, they are searching for a more free experience than the structured experience found in a museum. "It is said that the recreational visitor to a park or museum has an attention span operating at about a $4^{\text {th }}$ grade level." ${ }^{124}$ It is important to provide educational materials as an optional feature to the public art object which is generally demanding on its own. Keeping this in mind, the following examples of education tools used to teach audiences about the public art in their cities are new and accessible as options which is an important factor for people who view art. Most common education tools are plaques or signs placed near artworks that generally provide limited information. Other public art committees are utilizing QR codes near the works so that people who wish to be more informed can do so through their phones. This not only links viewers to ample information but also prevents a distraction (such as a sign) from invading the art space. Additionally, in

\footnotetext{
${ }^{122}$ Bad at Sports, Contemporary Art Talk, "Public Enemies: The Problem with Public Art," last modified June 4, 2012, http://badatsports.com/2012/public-enemies-the-problem-with-public-art/.

${ }^{123}$ Bad at Sports, Contemporary Art Talk, "Public Enemies: The Problem with Public Art."

${ }^{124}$ Bad at Sports, Contemporary Art Talk, "Public Enemies: The Problem with Public Art."
} 
Frankfort, Kentucky, a cell phone tour for public art, called Frankfort Public Art Tour, is available for visitors who wish to walk around the city and learn more about the art and history in the area. Information can be acquired by simply calling a phone number and selecting the art on view. Offering tours and educational opportunities that are easily accessible and engaging will hopefully reduce the misinterpretations assumed by the public and educate them instead on concepts of public art.

The purpose of public art is to provide opportunities for artistic and aesthetic interactions in the daily lives of people. Yet, for some reason, art has always carried a higher "hobby" value than, for example, sports. ${ }^{125}$ The education issue will remain an issue until people evaluate and find the most effective ways to interpret works of public art. After so many centuries of viewing art as a ruling faction over the people, public art today should embrace the educational opportunities to create a stronger, united public of equal measure. "Visual art, like our shared public space, reacts with time, conditions, and individuals who engage with it." 126 Public art also has the ability to "reach across age, race, language, and class differences, and provides a new way for people to engage directly on contemporary issues," ${ }^{127}$ by being free to visit and always open to the public.

It is through the concept of "for the public" that we approach the next contemporary issue of public art which determines the long-term success of a work of art: conservation. Advanced methods of conservation practices, including daily maintenance

\footnotetext{
${ }^{125}$ Bad at Sports Contemporary Art Talk, "Public Enemies: The Problem with Public Art."

${ }^{126}$ Creative Time, "Louisville Public Art Master Plan," (Plan for city of Louisville's Public Art Committee, Louisville, Kentucky, June 2009), 12. http://www.louisvilleky.gov/NR/rdonlyres/6679C445-41E9-4A8A9272-3C195740761E/0/PublicArtMasterPlanoptimized.pdf.

${ }^{127}$ Creative Time, "Louisville Public Art Master Plan," 12.
} 
practices, are crucial to the success of a work of public art. Lack of funding, weather conditions, and public interactions with the art are issues that concern conservation.

Public Art projects are typically funded by the following four groups: percent-forart programs via local city governments, grants offered by private corporations and foundations, private businesses who wish to fill their public spaces (i.e. front lobbies), and neighborhood groups who compose community projects. ${ }^{128}$ All four of these examples provide the monetary support for the production of a project. Financial support, with the exception of community-based projects, generally includes compensation for the artist as well as cost of materials and construction equipment if needed for installation. Current issues with public art budgets are the lack of expenses left for the continued care of the art. "Percent-for-art programs and public-private commissions often offer barely enough money for design, fabrication, and installation, and it is very rare for an artwork to come with maintenance funding or even with a written understanding of how long the object is meant to last or how to care for it." ${ }^{129}$ Certain materials are affected more by the weather and people's interaction. As artists expand their material choices for outdoor public art, more attention to conservation practices for the work is required through caseby-case basis. Media such as "video, lighting, sound, cell phone apps, and the needs of changing software require a different kind of care than washing and applying protective coatings." ${ }^{\prime 30}$ However, lack of funding makes it difficult for professional conservationists

\footnotetext{
128 "What is public art?" last modified 2011, forecastpublicart.org/toolkit/didactic.html.

${ }^{129}$ Rika Smith McNally and Lillian Hsu, "Conservation of Contemporary Public Art," Conservation Perspectives: The GCI Newsletter Vol.27 No.2 (2012): 8.

${ }^{130} \mathrm{McNa}$ lly and Hsu, "Conservation of Contemporary Public Art," 8.
} 
to propose proper care for the art. "To avoid extensive and invasive treatments, regular maintenance of outdoor sculpture is crucial,"131 and better economically in the long run.

Daily maintenance can solve normal or expected "wear and tear" problems like weather breaking down the gleam of paint or an increase of patina on bronze works. It also can help the caretaker to note changes in the art such as cracks and scratches which eventually can be repaired by contacting the artist or committee in charge of the project. Unfortunately, spray paint, gum, and other types of vandalism, are harder to treat and require more care than the daily routine maintenance practices. Vandalism is sometimes unavoidable, although many committees try to install work in open, well-lit areas which may prevent the artwork from being vandalized.

Throughout history, many people have reacted in strong ways to public art through vandalism and they continue to do so today. Political statues are knocked down by citizens' reaction to freedom from confining leadership. Religious sculptures are often broken as acts of rebellion. Public art is a huge target during war as it represents opposing cultures. It is unfortunate that political, religious, racial, and cultural oppositions urge people to violate art when art could really be an educational tool to understanding the opposing viewpoints. The New York Times shared an article about an exhibition held at the Tate Britain museum titled "Art Under Attack" which exposed the vandalized and irreparable artwork in their collection. It is a touchy subject among the art world because of the notion that discussion of such attacks may provoke more of them. ${ }^{132}$ This

\footnotetext{
${ }^{131}$ McNally and Hsu, "Conservation of Contemporary Public Art," 13.

132 Tom Rachman, "Passion, Principle or Both? Deciphering Art Vandalism," New York Times: Art \& Design, September 30, 2013, accessed October 2, 2013, http://nytimes.com/2013/10/01/arts/design/artunder-attack-at-tate-britain-explores-motives.html.
} 
exhibition, however, is important to the research of understanding what it is about public art that makes people so passionate and emotional that they wish to destroy it.

As artists continue to create works of new media, daily maintenance and longterm conservation instruction is crucial to the evaluated success of a work of art. In order for generations to identify and appreciate a work of art in their community, conservation budgets are necessary.

Today, "public art lacks a history or science of criticism proper to itself. There is a need of a critical theory with terminology that distinguishes public art from private art and makes its principles comprehensible to the public it addresses." ${ }^{\prime 133}$ Due to the many types of public art, evaluation procedures, the third issue of contemporary public art, seems to require a case-by-case evaluation and results should expand beyond "people's positive comments, or the fact that the artwork doesn't get covered with graffiti" ${ }^{\prime 134}$ as successful data sources. "Unlike museums or performance spaces, public art traditionally doesn't sell tickets, or attract 'audiences' who can easily be counted, surveyed, or educated." 135 This presents a major challenge for the field of public art as it has to find ways to evaluate public art without having the resources of a museum, gallery, or performance space. Measuring the success of public art is especially difficult because there are no set guidelines for evaluation and some evaluation methods are still being tested. For example, community or neighborhood projects are fascinating subjects as far as studying the impact they have on the community. While no results have been reported yet, evaluations are being conducted to see if there are correlations between the

\footnotetext{
${ }^{133}$ Hilde Hein, Public Art: Thinking Museums Differently, (Oxford: Altamira Press, 2006), 97.

${ }^{134}$ Katherine Gressel, "Public Art and the Challenge of Evaluation," Createquity, last modified January 7 , 2012, http://creatquity.com/2012/01/public-art-and-the-challenge-of-evluation.html.

135 Gressel, "Public Art and the Challenge of Evaluation."
} 
cleanliness of the area or increased community events after the public art project is completed. This type of evaluation measures success of the art in terms of influencing a better lifestyle for the surrounding community.

Ixia, a public art think tank and organization of Arts Council England, developed a public art guide to evaluation in 2010 that aims to "provide an independent and objective view of the factors that affect the quality of artists' work in the public realm by undertaking research, enabling debate and effecting change at a strategic level." "136 This step by step guide introduces the benefits of evaluations and provides possible methods for evaluating public art. It identifies four common resistances to evaluating, including: financial and time constraints, bureaucratic barriers, lead responsibility (who is in charge), and artistic barriers. ${ }^{137}$ Many of these, especially the issue of financial and time constraints, are major reasons for the lack of evaluations performed on art. By measuring the outcomes of a project, both short-term and long-term impacts, public artists and art committees can identify which types of materials, concepts, and interests the public appreciates. Results could also display statistics that promote economic benefits.

Evaluation, according to Ixia, is not something that is only performed at the final stages of a project. It also should be included throughout the development of the project and perhaps calls for an evaluation of the work years after its installation. Ixia has provided a Matrix which, if filled out at proper stages throughout the development of the project, can identify the committees' priority interests in the four value categories which measure public art success: artistic, social, environmental, and economic. This Matrix is a

\footnotetext{
${ }^{136}$ Ixia public art think tank, "Public Art: A Guide to Evaluation," accessed February 10, 2014, ixiainfo.com/files/2010/04/public-art-a-guide-to-evluationmarch10.pdf.

137 "Public Art: A Guide to Evaluation," Ixia: 4.
} 
tool that promotes discussion and debate on the priorities of the artwork's development and eventual predicted long-term success. ${ }^{138}$ It is unclear as to whether anyone in the United States has adopted this procedure for evaluating public art. ${ }^{139}$

Recently, the Manifesto of Possibilities, a manifesto about public art in urban environments, written by Cameron Cartiere, was published. This manifesto is written for public art commissioners and businesses to encourage them to utilize artistic practices as solutions to problems concerning non-art related fields. After reading the manifesto, they can evaluate their methods for obtaining and producing the art work in new ways. As artists are welcomed into non-cultural fields of work, the guidance and questions found in this manifesto provide insight of possibilities to those unfamiliar with artistic practices.

One of the most common evaluation methods for public art's contribution to a city's community identity and cultural values are economic reports. Research shows that "cities with an active and dynamic cultural scene are more attractive to individuals and businesses." 140 The better planned and artistically designed areas are engaging for visitors which reflects the economic success of the businesses in those areas. The city of Louisville, Kentucky revealed results from an economic report delivered in 2007 which indicated an increase of job opportunities from about 400 in 1986 to 5000 in 2007 because of the installation of their aesthetically designed urban park (which contains recreation activities and art installations). ${ }^{141}$ Despite these benefits, the results do not reveal a true evaluation of public art as its own entity. "A public artwork's role in

\footnotetext{
138 "Public Art: A Guide to Evaluation," Ixia: 7.

139 Gressel, "Public Art and the Challenge of Evaluation."

${ }^{140}$ Americans for the Arts Blog, "Why Public Art Matters," Public Art Network Council: Green Paper, blog.artsusa.org/category/public-art-greenpaper/.

141 Patrick Bartenstein, "Economic Report, the Impact of Louisville's Waterfront Park," Fall 2007, Accessed February 20, 2014, http://www.louisvillewaterfront.com/documents/Economic_Impact_2007.pdf
} 
economic revitalization is difficult to separate from its overall surroundings." ${ }^{142}$ The lack of evaluation procedures that identify the benefits of public art as art is one of the biggest criticisms that the field of public art faces today. This criticism is often linked to the financial and time constraints for an organization who wishes to provide proper evaluation methods for artwork.

If financial and time constraints are a major issue for an organization to evaluate public art projects, then the following five procedures developed by Katherine Gressel will prove beneficial to evaluating the work with institutions that have smaller budgets and time constraints. The first idea is archiving press coverage. Clipping articles is a great way to study reactions of art critics and the general public. Even archiving blogs can indicate a response from a non-art professional.

The second is observation of controversy over a work of public art. This can indicate the artists' success in displaying content. Reactions are the proposed results of public art, and managing controversy can indicate what a community wishes or does not wish to see in a certain area. Reactions can also indicate the need for more information about the artwork.

Third, site visits to observe public interaction with the art reveals the public's interest. If an organization does not have the time to complete this task themselves, they should consider hiring interns or volunteers. Professor Harriet Senie, public art historian at City University of New York, requires her students to complete a public art watch during the semester. "For the duration of the semester, on different days of the week, at different times, students observe, eavesdrop, and engage the audience for a specific work

\footnotetext{
${ }^{142}$ Gressel, "Public Art and the Challenge of Evaluation."
} 
of public art." ${ }^{143}$ This public art watch idea would be beneficial to see how people treat the works of art and clarify if a majority of viewers are tourists or city dwellers, and even learn if the observers are knowledgeable about the work of art prior to seeing it in person.

If interns or volunteers for specific tasks such as this are not available, community "proxies" are another option. Organizations involved with the public art project can approach local stores and ask the owners and employees to keep tally on how often the work of art is mentioned in their presence.

Fourth, residential surveys can be distributed on a time-restricted basis and collected for results. This method, while it may produce great responses from some residents, is faulty as other residents may not even respond. However, results from these surveys allow an organization to see what characteristics of their city's artwork are valued.

Last, using technology as a method for educating an audience can produce positive results. Supplying a QR code on the site of the artwork, creating an App for a phone, providing a phone number which gives an automated phone tour, and sharing websites are all methods of measurement. They can all be tracked as far as views or downloads are concerned. Increased amounts of downloads and views indicate how many people are reading about the work of art. Overall, the factors of site specificity, artist's intentions, patron's intention for commission, and public response can provide measurable features for evaluation.

The critical issues of contemporary public art in urban parks - research, public's reaction and interaction, maintenance and conservation, and lack of evaluation

\footnotetext{
${ }^{143}$ Gressel, "Public Art and the Challenge of Evaluation."
} 
procedures - all interconnect. Good communication between opposing perspectives in the project committee allow formative evaluation procedures for the project to be defined. Positive results from evaluations through public participation will promote financial support for future projects. Events that encourage educational experiences for the audience will influence the acceptance and public's interaction with the work. As the field of public art continues to expand, the evaluation procedures and professional practices for public art must be developed, agreed upon generally by the field, and become a useful standard to guide practices in the field. 


\section{CHAPTER FIVE}

\section{CASE STUDY: LOUISVILLE WATERFRONT PARK}

Influenced by the river, the city of Louisville, Kentucky, has grown to be a publicly-oriented, recreational and visual arts community enriched by its historic and cultural beginnings. During the mid $-19^{\text {th }}$ century, when river transportation prospered, ports along the city of Louisville's riverfront developed and the wharf industry grew. The Ohio River presented the natural beauty and history of the Falls of the Ohio (rapids created by layers of limestone). It also presented a natural access point between water and land, forming a bustling commerce space for the city. After World War II started, the interest in river travel declined as automobile transportation took its place and the wareffort changed riverside industrial practices. As the riverbanks became less important to business, the city searched for ways to renovate the waterfront into spaces for public recreation. The purchase of the Belle of Louisville steamboat in 1960 restored the city's love for its contribution to river history. "Since then, renewed interest has led to continued redevelopment of waterfront real estate, and a renaissance of riverfront related interest in the community." 144 The city of Louisville began a pivotal turn in their history, as it introduced plans for a recreational, business-driven, artistic and visually cultured waterfront through the development of Waterfront Park. Even though 1990 is relatively

\footnotetext{
144 “Louisville Waterfront Park," accessed January 14, 2014, http://www.louisvillewaterfront.com/.
} 
late as compared to other park developments in the United States, Louisville had the opportunity to observe, and study other city parks - both successes and failures. The difference in time allowed sufficient research to contribute to the current success of Waterfront Park. The following description of the Waterfront Park planning and phases of development explain how significant research connecting the city to its history and aesthetic design can contribute to a public's interest, economic success, and recreational participation. Public art has been and continues to be a significant component in this planning process as well.

The city's strong interest in green spaces, public spaces, and historic values formed the Waterfront Development Corporation (WDC) in 1986 which continues to develop park spaces and plan events for the enjoyment of the city public. WDC is responsible for the construction of one of the city's largest attractions known as Waterfront Park which was begun in 1990. After a series of public hearings, the park established plans for three design phases under the artful guidance of Hargreaves Associates. Their plan, fully developed in 1992, won the National Urban Planning Award from the American Society of Landscape Architects and incorporated traditional characteristics of public spaces and gardens from the Renaissance onward.

The Master Plan for Waterfront Park highlighted the river as a focal point of the city's heritage and recreation. It defined proposals for public components (lawns, water features, festival space, public wharf, recreation areas, etc.), commercial components (housing, retail, business and offices, etc.), and support components (parking, transportation and pedestrian access and flood protection). After analyzing site conditions that concerned the park's proposed location, including obstacles such as Interstate 64 
traveling through the park, the project concept was fully established and ready for approval. ${ }^{145}$ Traditional garden characteristics utilized in Italian gardens during the late Renaissance such as use of perspective, water features, and bosco (or heavily wooded areas) and characteristics found in city gardens developed in late $18^{\text {th }}$ century France, are primary components in the aesthetic design of this contemporary park. The Waterfront Park Master Plan pays attention to the public's desire for connections to the river. As listed in the plan's introduction, phrases such as "let the river be the river," and "let the Waterfront design come from the natural ecology of the river's shore, and find its way into the city," emphasize the urge to keep the river as the leading perspective throughout the park's development. ${ }^{146}$ This plan incorporates biking and walking trails among aesthetic landscape design and art installations. Each of the three phases propose different projects and installations that encourage educational, visual and recreational experiences for visitors.

Phase I, completed in 1999, consists of 55 acres and includes several well-known features of the park including the Wharf and Festival Plaza, the Overlook, Harbor Lawn and Inlet, a 900 foot long water feature and the Great Lawn. This phase of the park literally connects the river to the city through the largest gathering space in the park known as the Great Lawn. This Lawn, about 14 acres in size, starts at the river and slopes slightly upwards, under the expressway, towards the city edge of the park on Witherspoon Street. As the centerpiece of the park, this lawn is a "symbolic reenactment

\footnotetext{
${ }^{145}$ Hargreaves Associates, Louisville Waterfront Development Corp., "Louisville Waterfront Master Plan," (Business plan for the city of Louisville's Waterfront Park, Louisville, Kentucky, October 1991), 15. http://www.downtowndevelopmentcorp.com/Portals/83/Louisville\%20Waterfront\%20Master\%20Plan\%20 1991.pdf.

${ }^{146}$ Hargreaves Associates, "Louisville Waterfront Master Plan,” 1.
} 
of the clearing of Louisville's shore by European settlers." 147 The slope of the Great Lawn mitigates the Interstate 64 barrier allowing a clear view of the river from the Entry Plaza of the park down to the water. ${ }^{148}$ The Great Lawn is used by many for lounging, playing sports, viewing the event Thunder Over Louisville, and viewing concerts organized by WDC. As explained in Chapter 3, Jan Gehl's design for a lively city includes spaces such as the Great Lawn which provides much room for "meeting spaces" (or places where people can interact).

Adjacent to the south side of the lawn is a 900 foot long water feature which mimics the Falls of the Ohio through a series of cascades from Witherspoon Street into the Ohio River. The Falls of the Ohio were a major reason for Louisville becoming a large port for river transportation, and this water feature acts as a tribute to that historic reference. At the start of this water feature is the interactive fountain called Dancing Waters. With a similar idea to the inter-active water spouts created in 1612 in the gardens of Hellbrunn, Germany, the unpredictable bursts of water coming from the ground entice visitors into daily play. While water displayed the wealth of the owner of gardens of the late Renaissance through the early part of the 1800 's, the water features found at Waterfront Park convey a democratic feature for all audiences to interact, primarily because it is accessible for all visitors to enjoy.

In addition to the interactive water sculptures, other forms of art can be found throughout the park. All of the art is placed in specific areas, which promotes the concept of perspective developed in the Renaissance gardens. Each sculpture resides as a destination point along the pathways through the park. Continuing with Phase I, an

\footnotetext{
${ }^{147}$ Hargreaves Associates, "Louisville Waterfront Master Plan," 16.

${ }^{148}$ Hargreaves Associates, "Louisville Waterfront Master Plan," 32.
} 
example of a prominent sculpture in the park rests on a higher plane between the water feature and the Great Lawn, known as the Overlook. This tertiary space provides ample seating with views of the river and the large installation sculpture titled The Gracehoper, by Tony Smith. While the Overlook intends the river to be the perspective focus, The Gracehoper, currently a looming monument at 23' x 22' x 46', also steals attention from passers-by. This sculpture is a black, painted steel structure composed of geometric shapes. The title references the literary beast from James Joyce's novel Finnegan's Wake. Currently on loan to WDC from the Kentucky Arts Center, this work was moved to The Overlook location in 1989 and resides there still. A small plaque informs visitors of its significance, but unfortunately, the work has required repairs several times due to graffiti. In 1994, records indicate that the sculpture was surveyed by the organization known as Save Outdoor Sculpture! which, at the time, recorded the sculpture as being properly maintained. It is now part of the online art database for the Smithsonian Institute. ${ }^{149}$ The large scale allows visitors to explore the work by walking around and under it. It also can be viewed from a distance in the park and when driving along the expressway that overlooks the waterfront. The option of views allowed this work to become a recognizable symbol for the city, fulfilling the role expected from most public art that is placed in direct view in a public space.

On the other side of the Great Lawn from the Overlook are Phase I features known as Harbor Lawn and Harbor Inlet. Harbor Lawn is a triangle-shaped manicured space that is often used for small gatherings and weddings. Harbor Inlet represents the

\footnotetext{
${ }^{149}$ Smithsonian American Art Museum and the Renwick Gallery, "Save Outdoor Sculpture," accessed March 2, 2014, http://americanart.si.edu/research/programs/sos/.
} 
former wharf industry of Louisville and acts as a current docking area for recreational boats.

Lastly, and also most traditionally, near the Entry Plaza of the park at the base of the Great Lawn near Witherspoon Street, are the Public Gardens. "Public Gardens have traditionally been incorporated into city designs as oases or retreats from the rigors of everyday urban life, and as a public space for inhabitants to gather, to see and be seen."150 The Public Gardens designed for Waterfront Park are no exception. As a seasonal characteristic to the park, the flowers are surrounded by walkways and benches, allowing people to enjoy, interact, and watch others who pass by in this area. This concept has been a feature of city parks since the late 1700's when French citizens gathered in city parks for promenades.

Added later to the Phase I section of Waterfront Park are two art installations that reside in public view. Away from the river at the corner of Witherspoon Street and Preston are 29 colorful birds that replicate the wooden bird sculptures created by Louisville artist Marvin Finn. These birds were fabricated by Hick's Equipment and painted by Melissa Wilson, and installed by the Advisory Committee under Mayor Armstrong in 2000. In 2009, due to chipped paint and normal wear on the work, the work received restoration and was installed in its original location. Fortunately, costs of repairs was funded by the endowment set up for the collection and cost $\$ 5,000$. As a flock, the 29 birds are playful and unique, and act as a tribute to the artist as well as encourage an appreciation for local art. ${ }^{151}$

\footnotetext{
${ }^{150}$ Hargreaves Associates, "Louisville Waterfront Master Plan," 34.

${ }^{151}$ Broken Sidewalk, February 12, 2009, "Flock of Finns Migrates Back To Waterfront Park," http://brokensidewalk.com/tag/flock-of-finns/.
} 


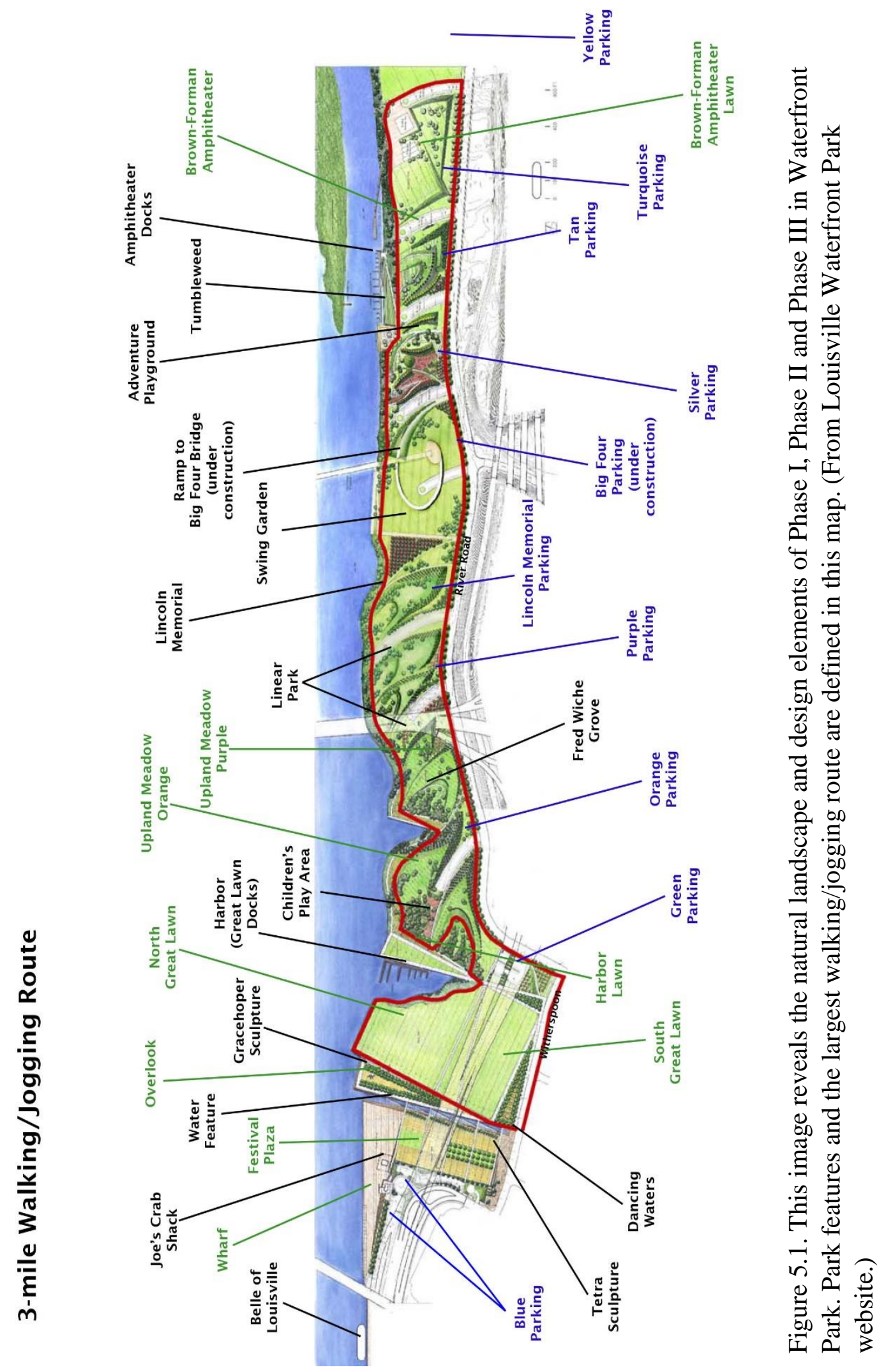


The second significant work of art in Phase I section is a sculpture created by sculptor Charles O. Perry called Tetra. Perry created mathematically-inspired, geometric, sculpture work for parks and gardens throughout the United States. ${ }^{152}$ Tetra resides in a rectangular plaza adjacent to the water feature and the Wharf. This abstract sculpture of manipulated steel entices visitors to travel down the pathway towards it and the water.

Phase I encompasses the most acreage and most open space. The total expense for this section of the park was $\$ 58$ million which was provided by WDC through private and public donations. This space is considered "the park's most distinctive open space," ${ }^{153}$ because it is well-used and recognized by its citizens. ${ }^{154}$

Phase II, completed in 2004, is significantly smaller than Phase I and lies north along River Road. The landscape design found here are part of a sub-park in Waterfront Park called Linear Park. Linear Park's landscape includes valleys, inlets, islands, hills, and vegetation. The purpose of this natural environment is to "recall the historic natural landscape of the Ohio Valley while provid[ing] places of prospect and refuge - for outdoor activities and environmental interaction."155 (Figure 5.1) Linear Park contains the most vegetation and wooded areas (or bosco) in Phase II. Among the natural hills and valleys are "a ribbon of medium to small"156 gathering spaces where picnics, family reunions, and weddings are encouraged by the WDC. This phase consists of 17 acres and includes the Adventure Playground, the Brown-Forman Amphitheater, the Brown-

\footnotetext{
152 William Grimes, "Charles O. Perry Dies at 81; Sculptor Inspired by Geometry," New York Times, February 11, 2011, accessed February 18, 2014, http://www.nytimes.com/2011/02/11/arts/design/11perry.html?_r=1\&.

${ }^{153}$ Louisville Waterfront Park, accessed January 14, 2014, http://www.louisvillewaterfront.com/.

${ }^{154}$ Louisville Waterfront Park, accessed January 14, 2014, http://www.louisvillewaterfront.com/.

${ }^{155}$ Hargreaves Associates, "Louisville Waterfront Master Plan," 35.

${ }^{156}$ Louisville Waterfront Park, accessed January 14, 2014, http://www.louisvillewaterfront.com/.
} 
Forman Lawn, Tumbleweed Southwest Grill, The Promenade, and several walking paths. The total cost of this section of the park was $\$ 15$ million. Utilizing the idea defined as rus in $u r b s$ (a rural retreat in the urban space), which has been a feature of gardens for centuries, Phase II of Waterfront Park is considered to be "a place where it is possible to feel nature without a reminder that the city is right over your shoulder." ${ }^{157}$ Many areas of shade, rest, and play are prominent here which makes this area one of the busiest sections of the park during the summer.

Phase III, completed in 2009 (except for the Big Four Bridge and Ramp), is the smallest section of the three phases consisting of 13 acres. This area of the park is composed of the Swing Garden (rows of bench swings) and despite its small size, it contains the two other most significant features of the park other than the Great Lawn: The Lincoln Memorial and the Big Four Pedestrian Bridge.

The Lincoln Memorial is one of the most extensive artwork installations in the park. Created by local artist Ed Hamilton, this installation includes a large statue of Abraham Lincoln resting on a rock façade surrounded by amphitheater seating. A pathway with stations of bronze reliefs that illustrate a timeline of slavery history leads visitors to the Lincoln statue. This installation, completed in 2009, presents the city's committee planning and research accomplishments for public art. WDC President David Karem explained that the committee for this project had to be sure to create these three clear messages: "the memorial should portray Lincoln as an approachable figure; it should have a strong educational linkage to Kentucky, and finally, the memorial should

${ }^{157}$ Louisville Waterfront Park, accessed January 14, 2014, http://www.louisvillewaterfront.com/. 
take full advantage of Lincoln's connection to the Louisville waterfront." ${ }^{\text {"58 }}$ All three of these messages are evident throughout the installation. The Lincoln sculpture is approachable because Hamilton chose to portray a young Lincoln resting on natural settings with a book in hand. To promote education, visitors can utilize the "Lincoln Memorial Visitors/Student Activity Guide" found on the Louisville Waterfront Park website. It this packet, the planning, construction, and reference to Lincoln's Kentucky history is available. It also prompts visitors with questions as they walk through the installation. Finally, as research has shown, Lincoln once wrote to his friend Joshua Speed in Louisville about a "scene on a boat bound for Louisville's waterfront with shackled slaves on board." ${ }^{159}$ This is why Lincoln faces away from the city and looks at the river, referencing this memory from Louisville that influenced his perspective on slavery. This memorial was part of the Phase III budget of \$22 million.

This Big Four Bridge is made from a spiral pathway that leads up to an abandoned railway bridge that crosses the river to Indiana. Wide enough for pedestrians and cyclists, this path has become a well-known attraction for the park. It is also well-lit at night with colorful fluorescents which provide an attraction for the travelers on the nearby Interstates. The final path of this bridge will connect Southern Indiana's waterfront to Kentucky, however, even though Kentucky's side is complete, Indiana has yet to complete construction. Similar to the resourceful design of the High Line in New York, this pedestrian bridge renovated an abandoned railway bridge, promoting a sustainable and cost-effective way to create attractions for the public. The total projected

\footnotetext{
${ }^{158}$ Ed Hamilton, Creating the Lincoln Memorial at Waterfront Park (Louisville: Chicago Spectrum Press, 2009).

${ }^{159}$ Ed Hamilton, Creating the Lincoln Memorial at Waterfront Park.
} 
cost for this phase is $\$ 22$ million, but without the Bridge's completion, the total is not confirmed.

Recently, the WDC has announced a new plan for the park's expansion of the park between $10^{\text {th }}$ and $14^{\text {th }}$ streets which adds 22 acres of space that would promote exercise and areas for escape from bustling city life. David Karem, President of WDC, states, "We've coined this term 'exerscape." 160 Similar to the activities found in the contemporary version of Central Park, Waterfront Park is focused on providing many recreational opportunities among a landscape retreat. In addition to new areas for recreation and retreat, the team is negotiating the addition of an iconic Ferris wheel. As WDC's original mission states, that WDC will "co-ordinate riverfront development and recreate a place where nature and the city-edge meet in a way that provides a unique atmosphere for public recreation." 161 The committee is fulfilling their mission by expanding the park and therefore expanding opportunities for park visitors. No plans or cost estimates have been released to the public yet, however predictions are that these plans will receive public approval.

At the conclusion of the Waterfront Park's Master Plan, it states: “...it is the spirit of the people who fill this space that adds the final dynamic." ${ }^{162}$ As Jan Gehl revealed in his guidelines for urban planning, a public reacts to the artistic and well-designed aspects of a city. The better the city design, the more lively the public. Surveys conducted by the City of Louisville's Park and Recreation Department indicate that many visitors to parks

\footnotetext{
${ }^{160}$ Michelle Arnold, "Committee may bring Ferris wheel to Waterfront Park," Last modified February 10 , 2014, http://www.whas11.com/news/local/Committee-may-bring-ferris-wheel-to-Waterfront-Park244762131.html.

161 Arnold, "Committee may bring Ferris wheel to Waterfront Park."

${ }^{162}$ Hargreaves Associates, "Louisville Waterfront Master Plan," 41.
} 
enjoy the space provided. In one survey, the question asked participants to rate how safe they feel in Louisville's Parks during the day, resulting in a high $89 \%$ for "Very Safe" in 2012 (Figure 5.2). Another survey asks the participants to rate their opinion of the condition of the parks, bike paths, playing fields, and playgrounds which resulted as 50\% saying excellent condition and $44 \%$ saying good condition. Lastly, a survey was performed to analyze what aspects of the city's character were essential. Safety/low crime, Open Space, and Passive/Active recreation amenities (trails, recreation center, parks) all received $74 \%, 72 \%$, and $71 \%$ respectively as essential to the characteristic of the city of Louisville (Figure 5.3). Even though the city of Louisville contains many parks, some of which were designed by Frederick Law Olmstead, the results of these surveys conducted in May 2012 include the Waterfront Park. Such high results indicates the appreciated response citizens feel for their park spaces in the city.

Further impact on the public can be found in the Economic Report compiled in 2007 which reveals the business benefits brought to the city by the development of Waterfront Park. Even though the local government provides monetary support for the day-to-day operations and maintenance of the park, "WDC relies heavily on private and public donations to fund the construction of Waterfront Park." ${ }^{163}$ Fortunately, the previously under-developed areas along the waterfront have proven to be a positive

\footnotetext{
${ }^{163}$ Patrick Bartenstein, "Economic Report, the Impact of Louisville's Waterfront Park," accessed February 20,2014, http://www.louisvillewaterfront.com/documents/Economic_Impact_2007.pdf.
} 
Since 2004, respondents have been asked to rate how safe they felt in various areas throughout the city. Generally, Louisville residents reported feeling safe in the city. Almost all respondents ( $92 \%$ or more) felt "very" or "somewhat" safe in each of the various areas around Louisville.

All safety ratings were much above those given by residents in other communities across the nation and in the Front Range.

Table 6: Safety in Various Public Areas

\begin{tabular}{|c|c|c|c|c|c|c|c|c|}
\hline $\begin{array}{l}\text { Please rate how } \\
\text { safe you feel: }\end{array}$ & $\begin{array}{l}\text { Very } \\
\text { safe }\end{array}$ & $\begin{array}{c}\text { Somewhat } \\
\text { safe }\end{array}$ & $\begin{array}{l}\text { Neither } \\
\text { safe nor } \\
\text { unsafe }\end{array}$ & $\begin{array}{c}\text { Somewhat } \\
\text { unsafe }\end{array}$ & $\begin{array}{c}\text { Verv } \\
\text { unsafe }\end{array}$ & Total & $\begin{array}{c}\text { National } \\
\text { comparison }\end{array}$ & $\begin{array}{l}\text { Front Range } \\
\text { comparison }\end{array}$ \\
\hline $\begin{array}{l}\text { In Louisville's } \\
\text { downtown area } \\
\text { during the day }\end{array}$ & $93 \%$ & $7 \%$ & $0 \%$ & $0 \%$ & $0 \%$ & $100 \%$ & Much above & Much above \\
\hline $\begin{array}{l}\text { In your } \\
\text { neighborhood } \\
\text { during the day }\end{array}$ & $92 \%$ & $7 \%$ & $1 \%$ & $0 \%$ & $0 \%$ & $100 \%$ & Much above & Much above \\
\hline $\begin{array}{l}\text { In Louisville's } \\
\text { parks during the } \\
\text { day }\end{array}$ & $89 \%$ & $9 \%$ & $1 \%$ & $0 \%$ & $0 \%$ & $100 \%$ & Much above & Not available \\
\hline $\begin{array}{l}\text { In Louisville's } \\
\text { downtown area } \\
\text { after dark }\end{array}$ & $66 \%$ & $31 \%$ & $2 \%$ & $0 \%$ & $0 \%$ & $100 \%$ & Much above & Much above \\
\hline $\begin{array}{l}\text { In your } \\
\text { neighborhood } \\
\text { after dark }\end{array}$ & $65 \%$ & $31 \%$ & $2 \%$ & $1 \%$ & $0 \%$ & $100 \%$ & Much above & Much above \\
\hline $\begin{array}{l}\text { In Louisville's } \\
\text { parks after dark }\end{array}$ & $43 \%$ & $46 \%$ & $8 \%$ & $3 \%$ & $0 \%$ & $100 \%$ & Much above & Not available \\
\hline
\end{tabular}

Figure 5.2. City of Louisville Citizen Survey, Safety in Various Public Areas. This table indicates the opinions of safety from the Louisville public in various areas of the city. Emphasis is placed on the feeling of safety in parks throughout the text. 


\section{City's Character}

To help the City prioritize potential projects, as in 2008 , survey respondents were asked to rate the importance of several aspects of Louisville's character. A number of new characteristic were added to the list in 2012. Safety/low crime (97\%), passive/active recreation amenities (95\%), overall City appearance/attractiveness (94\%), Louisville as a walkable/pedestrian-friendly community (93\%), the transportation system ( $92 \%$ ) and open space ( $91 \%$ ) were most important to residents, with 9 in 10 or more saying these were "essential" or "very important." Safety/low crime (74\%), open space (72\%) and passive/active recreation amenities (71\%) were "essential" to at least 7 in 10 residents.

Eighty-nine percent said that Downtown Louisville was "essential" or "very important" and 88\% said support for business was an "essential" or "very important." The characteristic named least frequently as being "essential" or "very important" to residents was the Coal Creek Golf Course, club house and amenities (28\%), followed by Louisville Historical Museum (47\%) and personal contact with City staff (55\%).

Table 27: Importance of Aspects of Louisville's Character

\begin{tabular}{|c|c|c|c|c|c|}
\hline $\begin{array}{c}\text { Please rate how Important, If at all, each of } \\
\text { the following aspects of Louisville's } \\
\text { character is to you: }\end{array}$ & Essential & $\begin{array}{c}\text { Very } \\
\text { Important }\end{array}$ & $\begin{array}{l}\text { Somewhat } \\
\text { Important }\end{array}$ & $\begin{array}{l}\text { Not at all } \\
\text { important }\end{array}$ & Total \\
\hline Safety/low crime & $74 \%$ & $23 \%$ & $2 \%$ & $0 \%$ & $100 \%$ \\
\hline $\begin{array}{l}\text { Passive/active recreation amenities (o.g., } \\
\text { trails, recreation center, parks) }\end{array}$ & $71 \%$ & $23 \%$ & $5 \%$ & $0 \%$ & $100 \%$ \\
\hline Overall City appearance/attractiveness & $57 \%$ & $37 \%$ & $5 \%$ & $0 \%$ & $100 \%$ \\
\hline $\begin{array}{l}\text { Louisville as a walkable/pedestrian-friendly } \\
\text { community }\end{array}$ & $66 \%$ & $27 \%$ & $6 \%$ & $1 \%$ & $100 \%$ \\
\hline $\begin{array}{l}\text { Transportation system (streets, highways, } \\
\text { bus system, trails) }\end{array}$ & $51 \%$ & $41 \%$ & $7 \%$ & $0 \%$ & $100 \%$ \\
\hline Open space & $72 \%$ & $19 \%$ & $7 \%$ & $2 \%$ & $100 \%$ \\
\hline Downtown Louisville & $59 \%$ & $30 \%$ & $10 \%$ & $0 \%$ & $100 \%$ \\
\hline $\begin{array}{l}\text { Support for businesses (a business friendly } \\
\text { climate) }\end{array}$ & $49 \%$ & $39 \%$ & $10 \%$ & $2 \%$ & $100 \%$ \\
\hline Louisville Public Llbrary & $57 \%$ & $29 \%$ & $12 \%$ & $2 \%$ & $100 \%$ \\
\hline Community avents & $33 \%$ & $39 \%$ & $27 \%$ & $1 \%$ & $100 \%$ \\
\hline Historic buildings & $31 \%$ & $35 \%$ & $28 \%$ & $6 \%$ & $100 \%$ \\
\hline Personal contact with City staff & $13 \%$ & $42 \%$ & $41 \%$ & $4 \%$ & $100 \%$ \\
\hline Louisville Hlstorical Museum & $14 \%$ & $33 \%$ & $41 \%$ & $12 \%$ & $100 \%$ \\
\hline $\begin{array}{l}\text { Coal Creek Golf Course, club house and } \\
\text { amenities }\end{array}$ & $10 \%$ & $18 \%$ & $31 \%$ & $41 \%$ & $100 \%$ \\
\hline
\end{tabular}

Figure 5.3. City of Louisville Citizen Survey, Importance of Aspects of Louisville's Character. This table reveals the Louisville public's thoughts about its city's character. Emphasis is placed on the top three categories in the text: Safety/low crime, open space, and passive/active recreation amenities. 
investment for businesses and citizens of Louisville. In the economic report, which reveals the impact of Waterfront Park on businesses, statistics indicate that since the beginning of Waterfront Park's planning and creation in 1986, job opportunities along the waterfront have increased from (+/-) 400 jobs in 1986 to (+/-) 5305 jobs in 2007. ${ }^{164}$ Even more beneficial, although no research has been revealed on this study to-date, a large majority of these businesses are within walking distance to the park. As mentioned in Chapter 3, the health benefits of working near a park or natural landscape are substantial in the workplace environment as it encourages a low-stress level atmosphere.

The lack of evaluation procedures indicating the economic success from the park is not the only subject of evaluation that is lacking. Like many other parks in the United States, evaluation procedures that survey the park and public reaction in addition to the art in the park are non-existent. As mentioned in Chapter Four, most organizations cannot fund or provide time for extensive evaluations and resort to random feedback from visitors as good sources for evaluation. While this type of feedback can provide honest results, it doesn't encompass a large public, which would provide more honest feedback.

During an email interview with WDC President David Karem ${ }^{165}$, it was confirmed that there is no formal evaluation for the art or the park. Karem states, "There are over 125 events per year in the park, each of which is unique in its own right, and trying to collapse those into one evaluation process would be nearly impossible." It is also difficult to create an evaluation for public art when there is no definite language developed for public art. Perhaps the WDC can take advantage of the time and cost-effective evaluation practices created by Katherine Gressel.

\footnotetext{
164 Bartenstein, "Economic Report."

${ }^{165}$ Karem, David, Interview with Taylor Crush, Personal Email Interview, Louisville, March 25, 2014.
} 
Karem continued to explain, however, that the informal "evaluation" they collect is feedback responses (given at random times) from the public, as many other parks do. "Nearly all of the feedback, if not all, about the art in the park has been positive." And, each artwork receives different reactions. The Flock of Finns, he noted, generally discusses how inviting and playful they are for pictures. On a different note, he indicated that the Lincoln Memorial is treated as a destination point for emotional responses rather than an area of play. Again, while verbal or quick written responses that share an individual's story with the WDC staff is truthful, it does not represent a large public's opinion and cannot count as a collected evaluation.

The other major concern about contemporary public art, described in the previous chapter, was conservation. In the same interview, Karem explained that they have been fortunate because the repairs from vandalism and normal wear-and-tear on the art has been minimal. The Gracehoper, according to Karem, probably receives the most attention (in terms of scratches and signs of people interacting with it). Preventative care has included the patch of grass installed under the sculpture which separates it from the gravel path. Otherwise, the sculpture that has required the most maintenance is the Flock of Finns which is about to receive another fresh coat of paint to repair its faded colors. Most of the artworks require an outside contractor to repair the work. Some, such as the Flock of Finns, have a small budget allotted for repairs. Others must be budgeted for when problems arise. This has not been a problem, however, because of two reasons. First, as mentioned earlier, they have been fortunate in terms of minimal repairs required for the art work. Second, the WDC appointed Marlene Grissom, a nationally acclaimed 
art dealer, as the contact for all the art in the park. This position ensures that all the art will not be neglected.

The city of Louisville contains a deeply rooted history in the river. With the guidance of designs created by Hargreaves Associates, the Waterfront Development Corporation was able to entice the city public back to the riverbanks through a park setting that acts as a retreat, educational and visual arts space, and recreational environment. Inspired by garden characteristics from the late Renaissance, the city of Louisville has created a successful park that utilizes the examples of prominent parks constructed in other cities and encompasses the beneficial examples of public art and design in the Waterfront Park setting. The park design incorporated symbolic historical references in its aesthetic landscapes and provides contemporary artwork which promotes public involvement and interaction in the space. By reviving the public's love for the river that previously brought economic and cultural success, the park remains a space where the public can remember the past and integrate the river's success once more in the economic and recreational aspects of their lives. 


\section{CONCLUSION}

A counter-argument to the question what is the point of public art? is often to imagine a world, your city, or your life without public art. This means no design on public sidewalks, no statues commemorating loved ones, no places devoted by abstract shapes or colorful monuments. City identities and icons vanish and everything starts to appear homogenous. This mundane image alone allows one to realize that there is a purpose to public art because it influences the liveliness, culture, and identity of a city public. Jimmy Castillo, collection manager for Houston Arts Alliance, states that public art is important because it "adds variety and inspiration to your everyday life. You encounter it whether you want to or not, and whether you like it or not." 166 Art in the community serves the public by making the environment vibrant and engaging, provocative and disconcerting, or irritating and calming as art registers differently for everyone.

For centuries, art has been placed in public gardens and nature. Today, public art can be found in contemporary urban parks. While art in garden spaces is not a new idea, "the methods for creating parks and public spaces that easily become a thriving destination for a community have come a long way in the last 50 years."167 The specific placement or inclusion of art in parks emphasizes the publics' need and enjoyment of recreation mixed with pleasure. Studies have proven that nature is a natural stimulant for

\footnotetext{
166 Sandra Cook, “Designed to Inspire,” downtown, Spring 2014, 22.

167 Cook, "Designed to Inspire," 24.
} 
relaxation for the mind. Placing art in this environment only stimulates the mind in another, but related way. The reactions to a well-designed public art space are beneficial for the entire community in many ways as outlined in this thesis. It is the artist and producer's job to examine its community prior to undertaking the work. "When the community shapes the artists' vision, the art can truly define the place it resides." 168 Public art is often a tangible reflection of how a community views itself. The valuable icon it becomes will remain important so long as there are opportunities to observe the meaning of the work. Educational tools can aid the process and the value of the art. Educational tools, such as tours, inclusion of QR codes or cell phone tours, can inform visitors and city publics. Adaptive approaches to educational opportunities can redefine public art to make it available for generations.

However, the public's recognition of a public art's value and the incorporation of education methods for the work are not the only things that keep a work of art alive in the community. The value and pride placed on a work of art should emphasize the need for periodic (annual, monthly, bi-annual) conservation. Yearly maintenance is more economic in the long run, however, it is more difficult to manage a budget for yearly maintenance. Many organizations wait years or until vandalism forces a "fine-tuning" of a work. This is especially important as more artists begin to experiment and use new materials in their public art.

In time, perhaps with the guidance of Ixia's Matrix of Evaluation or another format, public art will develop a language that is unique to its genre. "A theory appropriate to public art would explain its social function and amplify the meaning of

${ }^{168}$ Cook, "Designed to Inspire," 24-25. 
constructing a public." 169 While no such language or universal guideline for public art is currently available, the development of this language and structure is necessary to measure its functional and artistic success in city parks and public spaces. The challenge for evaluation lies in the fact that there are numerous types of materials, concepts, and histories for public art. A lack of resources devoted to deciphering this challenge needs to be addressed in order to promote development in this field. A universal guideline would get the evaluations started, but the completion of the evaluations will require a case-bycase study and adaptation.

Overall, public art is a valued commodity in society. Social sculpture, as Joseph Beuys coined it, is a practical and important concept for public art. As more and more public artworks are created and installed in a community's environment, emphasis is placed on the idea that public art is made for routine activities rather than dramatic events. ${ }^{170}$ The variety of available public art offers a grounded experience for tangible audiences in their daily life that enriches, enhances and empowers everyone.

\footnotetext{
${ }^{169}$ Hilde Hein, Public Art: Thinking Museums Differently, (Oxford: Altamira Press, 2006) 97.

${ }^{170}$ Hein, Public Art: Thinking Museums Differently.
} 


\section{REFERENCES}

"A History of 100 Acres: The Virginia B Fairbank Art \& Nature Park." In 100 Acres, the Virginia Fairbank Art \& Nature Park, ed. Marlon Blackwell. Indianapolis: Indianapolis Museum of Art, 2010.

“A View on Cities: Rome.” Accessed January 10, 2014. http://www.aviewoncities.com/rome/piazzadelcampidoglio.htm.

"American Time Use Survey." Bureau of Labor Statistics United States Department of Labor. Accessed February 12, 2014. http://www.bls.gov/tus/charts/.

Americans for the Arts Blog. blog.artsusa.org/category/public-art-greenpaper/

Anderson, Maxwell L. Foreword to 100 Acres, the Virginia Fairbank Art \& Nature Park, ed. Marlon Blackwell. Indianapolis: Indianapolis Museum of Art, 2010.

Architectural Record. "New Art Parks Enliven Urban Centers.” Accessed January 4, 2014. http://archrecord.construction.com/news/daily/archives/091001art_parks.asp

Arnold, Michelle. "Committee may bring Ferris wheel to Waterfront Park." Last modified February 10, 2014. http://www.whas11.com/news/local/Committee-maybring-ferris-wheel-to-Waterfront-Park-244762131.html

"Association for Public Art.” Accessed January 8, 2014. associationforpublicart.org

Auricoste, Isabelle. "Leisure Parks in Europe: Entertainment and Escapism." In The Architecture of Western Gardens, eds. Monique Mosser and Georges Teyssot, 483 494. Massachusetts: the MIT Press, 1991.

Bad at Sports, Contemporary Art Talk. http://badatsports.com/2012/public-enemies-theproblem-with-public-art/

Bartenstein, Patrick. "Economic Report, the Impact of Louisville's Waterfront Park." Accessed February 20, 2014. http://www.louisvillewaterfront.com/documents/Economic_Impact_2007.pdf

Beardsley, John. Earthworks and Beyond: Fourth Edition. New York: Abbeville Press, 2006. 
Bergmann, Ralph. "CONNECT.” Bernheim Arboretum and Research Forest. Last modified August 24, 2013. Bernheim.org/?s=connect

Broken Sidewalk. http://brokensidewalk.com/tag/flock-of-finns/

Brooks, Katherine. "Don't Mess with Our Alexander Calder, Says Michigan Town." Huffpost: Arts \& Culture, September 26, 2013. Accessed November 13, 2013. www.huffingtonpost.com/2013/09/26/david-dodde_n_3995925.html

Careri, Giovanni. Baroques. New Jersey: Princeton University Press, 2003.

“Central Park.com.” Accessed January 18, 2014. http://www.centralpark.com/guide/general-info.html

“City of Houston, The.” Last modified 2014. http://www.houstontx.gov/parks/artinparks/ Comito, Terry. "The Humanist Garden." In The Architecture of Western Gardens, edited by Monique Mosser and Georges Teyssot, 37-45. Massachusetts: the MIT Press, 1991.

Cook, Sandra. “Designed to Inspire.” Downtown. Spring 2014.

Cranz, Galen. "The Reform Park in United States (1900-1930)." In The Architecture of Western Gardens, eds. Monique Mosser and Georges Teyssot, 466-468.

Massachusetts: the MIT Press, 1991.

Creative Time. "Louisville Public Art Master Plan.” Plan for city of Louisville's Public Art Committee, Louisville, Kentucky, June 2009. Accessed February 17, 2014.

http://www.louisvilleky.gov/NR/rdonlyres/6679C445-41E9-4A8A-9272-

3C195740761E/0/PublicArtMasterPlanoptimized.pdf

Dirt: Uniting the Built \& Natural Environments, The.

http://dirt.asla.org/2011/09/08/research-shows-nature-helps-with-stress/.

Dirt: Uniting the Built and Natural Environments, The. http://dirt.asla.org/2012/10/15/why-public-art-is-important/.

"Dorchester Projects." Theaster Gates. Accessed March 20, 2014. http://theastergates.com/section/117693_Dorchester_Projects.html

"Federal Art Programs." U.S. General Services Administration. Last reviewed November 12, 2013. www.gsa.gov/portal/content/101818

Frank, Regina. “Sculpting Urban Airspace Janet Echelman.” Sculpture, September 2011. 
Freiman, Lisa D. " 100 Acres: A Living Sculpture Park for the $21^{\text {st }}$ Century." In 100 Acres, the Virginia Fairbank Art \& Nature Park, ed. Marlon Blackwell. Indianapolis: Indianapolis Museum of Art, 2010.

Gehl, Jan. Cities for People. Washington, D.C.: Island Press, 2010.

Godbey, Geoffrey. "Outdoor Recreation, Health, and Wellness: Understanding and Enhancing the Relationship." Paper prepared for the Outdoor Resources Review Group for Resources for the Future Background Study, Washington D.C., May 2009.

Goss, Steven. "The Problems with Public Art: Does the Public Like Its Art?” Accessed February 10, 2014. http://theapesheet.com/archivesix/public/html.

Gressel, Katherine. "Public Art and the Challenge of Evaluation." Createquity. Last modified January 7, 2012. http://creatquity.com/2012/01/public-art-and-thechallenge-of-evluation.html

Grimes, William. "Charles O. Perry Dies at 81; Sculptor Inspired by Geometry." New York Times, February 11, 2011. Accessed February 18, 2014. http://www.nytimes.com/2011/02/11/arts/design/11perry.html?_r=1\&

Hamilton, Ed. Creating the Lincoln Memorial at Waterfront Park. Louisville: Chicago Spectrum Press, 2009.

Hamlin, A.D.F. "Some Thoughts on Old World Gardens." Art and Progress Vol. 5, No.7 (1914): 231-237. Accessed January 6, 2014. http://jstor.org/stable/20561150

Hargreaves Associates and Louisville Waterfront Development Corp., "Louisville Waterfront Master Plan.” Business plan for the city of Louisville's Waterfront Park, Louisville, Kentucky, October 1991. http://www.downtowndevelopmentcorp.com/Portals/83/Louisville\%20Waterfront $\% 2$ 0Master\%20Plan\%201991.pdf

Harper, Glenn, and Twylene Moyer. The New Earthwork: Art Action Agency New Jersey: isc Press, 2011.

Hartt, Frederick. Michelangelo. New York: Harry N. Abrams, Inc., 2004.

Hein, Hilde. Public Art: Thinking Museums Differently. Oxford: Altamira Press, 2006.

Hein, Hilde. "What is public art? Time, Place, and Meaning." The Journal of Aesthetics and Art Criticism Vol. 54, No. 1 (1996): 1-7. Accessed January 6, 2014. http://www.jstor.org/stable/431675.

Howells, Trevor. The World's Greatest Buildings. San Francisco: Fog City Press, 2002. 
"How Cities Use Parks for... Art and Cultural Programs." American Planning Association. Last modified 2013. http://www.planning.org/cityparks/briefingpapers/arts.htm.

Hunt, Jeremy and Jonathan Vickery. "Public Art in the $21^{\text {st }}$ Century." GROVE Art Online. Accessed January 10, 2014. www.oxfordartonline.com.

Ixia public art think tank. "Public Art: A Guide to Evaluation." Accessed February 10, 2014. Ixia-info.com/files/2010/04/public-art-a-guide-to-evluationmarch10.pdf.

Jordan, Harriet. "Public Parks, 1885-1914." The Garden History Society Vol. 22, No. 1, (Summer, 1994). Accessed January 6, 2014. http://jstor.org/stable/1587004.

“Joseph Beuys, 7000 Oaks.” Dia Art Foundation. Last modified 2012. www.diaart.org/sites/page/51/1364

Karem, David. Interview with Taylor Crush. Personal Email Interview. Louisville, March 25, 2014.

Knight, Cher Krause. Public Art: Theory Practice and Populism. Massachusetts: Blackwell Publishing, 2008.

Lazzaro, Claudia. The Italian Renaissance Garden. New Haven \& London: Yale University Press, 1990.

“Louisville Waterfront Park.” Accessed January 14, 2014. http://www.louisvillewaterfront.com/

McNally, Rika Smith, and Lillian Hsu. "Conservation of Contemporary Public Art." Conservation Perspectives: The GCI Newsletter Vol.27 No.2 (2012).

Michel, Marianne Roland. "Scenography and Perspective in Eighteenth-Century French Gardens." In The Architecture of Western Gardens, eds. Monique Mosser and Georges Teyssot, 243-252. Massachusetts: the MIT Press, 1991.

Miller, Sara Cedar. Central Park, an American Masterpiece. New York: Harry N. Abrams, Inc., in assoc. with Central Park Conservancy.

Mosser, Monique, and Georges Teyssot, "Introduction: The Architecture of the Garden and Architecture in the Garden." In The Architecture of Western Gardens, edited by Monique Mosser and Georges Teyssot, 11-23. Massachusetts: the MIT Press, 1991. 
Park, Bum Jin, Yuko Tsunetsugu, Tamami Kasetani, and Yoshifumi Miyazaki. "The physiological effects of Shinrin-yoku (taking in the forest atmosphere or forest bathing): evidence from field experiments in 24 forests across Japan." Environmental Health and Preventative Medicine 15:18-26. Accessed February 9, 2014. doi: 10.1007/s12199-009-0086-9.

Pohl, Frances K. “Art for People, Art Against Fascism.” In Framing America. New York: Thames \& Hudson, Inc., 2008.

Ponte, Alessandra. "Public Parks in Great Britain and the United States: From a 'Spirit of the Place' to a 'Spirit of Civilization." In The Architecture of Western Gardens, eds. Monique Mosser and Georges Teyssot, 372-386. Massachusetts: the MIT Press, 1991.

Puppi, Lionello. "Nature and Artifice in the Sixteenth-Century Italian Garden." In The Architecture of Western Gardens, edited by Monique Mosser and Georges Teyssot, 47-58. Massachusetts: the MIT Press, 1991.

Rabreau, Daniel. "Urban Walks in France in the Seventeenth and Eighteenth Centuries." In The Architecture of Western Gardens, eds. Monique Mosser and Georges Teyssot, 305-316. Massachusetts: the MIT Press, 1991.

Rachman, Tom. "Passion, Principle or Both? Deciphering Art Vandalism." New York Times: Art \& Design, September 30, 2013. Accessed October 2, 2013. http://nytimes.com/2013/10/01/arts/design/art-under-attack-at-tate-britain-exploresmotives.html

Ross, Deborah. "Temporary public art is rising in Phoenix - in myriad forms." Art Ltd., $\mathrm{Jan} / \mathrm{Feb} 2014$.

Senie, Harriet F. "Responsible Criticism: Evaluating Public Art." Sculpture Vol.22 No.10 (2003). Accessed February 15, 2014. http://www.sculpture.org/documents/scmag03/dec03/senie/senie.shtml

Smithsonian American Art Museum and the Renwick Gallery. "Save Outdoor Sculpture." Accessed March 2, 2014. http://americanart.si.edu/research/programs/sos/

Snodin, Michael, and Nigel Llewellyn, eds., assisted by Joanna Norman. Baroque, Style in the Age of Magnificence. London: V\&A Publishing, 2009.

Taylor, Hilary A. "Urban Public Parks, 1840-1900: Design and Meaning." The Garden History Society Vol. 23, No. 2 (1995): 201-221. Accessed January 6, 2014. http://jstor.org/stable/1587078 
Trust for Public Land, The. "Annual City Parks Data Released by the Trust for Public Land." Last modified December 8, 2011. http://www.tpl.org/media-room/annual-cityparks-data-released-trust-public-land.

Vérin, Hélèn. "Technology in the Park: Engineers and Gardeners in Seventeenth-Century France." In The Architecture of Western Gardens, eds. Monique Mosser and Georges Teyssot, 135-146. Massachusetts: the MIT Press, 1991.

"What is public art?" Last modified 2011. forecastpublicart.org/toolkit/didactic.html

Young, Terence. "Modern Urban Parks." American Geographical Society Vol. 85, No. 4 (1995): 535-551. Accessed January 6, 2014. http://www.jstor.org/stable/215924

Zangheri, Luigi. "Curiosities and Marvels of the Sixteenth-Century Garden." In The Architecture of Western Gardens, eds. Monique Mosser and Georges Teyssot, 59-67. Massachusetts: the MIT Press, 1991. 


\section{CURRICULUM VITA}

NAME: $\quad$ Taylor Crush

ADDRESS: 14 Leathers Road

Fort Mitchell, Kentucky 41017

DOB: $\quad$ Edgewood, Kentucky - September 20, 1990

EDUCATION

\& TRAINING: $\quad$ B.F.A. 3D Studies

Hite Art Institute

University of Louisville

2008-2012

M.A. Critical and Curatorial Studies

Hite Art Institute

University of Louisville

$2012-2014$

AWARDS: $\quad$ Outstanding Graduate in Fine Arts

2014

Hite Scholarship, Allen R. Hite Institute

2009-2013

Nora Iasigi Bullitt Memorial Scholarship in Sculpture

2011-2012

Mary Nay Spencer Memorial Scholarship, Allen R. Hite Institute 2008-2009 